\title{
Shorebirds, Stakeholders, and Competing Claims to the Beach and Intertidal Habitat in Delaware Bay, New Jersey, USA
}

\author{
Joanna Burger ${ }^{1}$, Lawrence Niles ${ }^{2}$ \\ ${ }^{1}$ Division of Life Sciences, Rutgers University, Piscataway, NJ, USA; ${ }^{2}$ Conserve Wildlife Foundation of New Jersey, \\ Greenwich, NJ, USA
}

Correspondence to: Joanna Burger, burger@biology.rutgers.edu

Keywords: Assessment, Aquaculture; Monitoring, Red Knot, Shorebirds, Intertidal, Recreationists, Horseshoe Crabs, Competing Claims

Received: April 28, $2017 \quad$ Accepted: June 26, $2017 \quad$ Published: June 29, 2017

Copyright $\odot 2017$ by authors and Scientific Research Publishing Inc.

This work is licensed under the Creative Commons Attribution International License (CC BY 4.0).

http://creativecommons.org/licenses/by/4.0/

(c) (i) Open Access

\section{ABSTRACT}

Birds have specific habitat needs as a function of their life cycle and reproductive stage. Migrant shorebirds that may fly from the Arctic to the southern tip of South America have foraging and habitat requirements at sites where they stop to refuel before continuing their migration north or south. Throughout the world, shorebirds mainly forage on mudflats at low tide. Red knots (Calidris canutus rufa) are threatened in the United States and elsewhere, and it is critical to determine factors that might contribute to their decline. This paper uses Delaware Bay as a case study to examine shorebird (and red knot) use of the intertidal habitat, and competing claims to habitats they require during their northward migration, as well as some of the key stakeholders that play a role in protecting red knots. Shorebirds are drawn to Delaware Bay to feed on the eggs of Horseshoe Crabs (Limulus polyphemus) that are concentrated at the high tide. But they also feed on the intertidal mudflat. We examined intertidal habitat use on 17 beaches in an extensive study in 2015, and 5 key beaches in 2016. Most of the beaches were longitudinal, but four were more complex, and were used extensively for resting as well as foraging; numbers there were higher than on the longitudinal beaches. On foraging beaches, some shorebirds were present on over $85 \%$ of the intertidal censuses, and red knots were present on over $48 \%$ of the intertidal censuses. Average numbers of red knots on the longitudinal beaches varied from 0 to $354 \pm 116$ when any shorebirds were present, but averaged up to $1184 \pm 634$ when knots were present in 2015 . Some beaches in 2015 had no knots (a beach with long-term aquaculture). Tide, intertidal location, and beach (name) determined the number of knots (and all shorebirds). Numbers decreased with distance from the mean high tide line. The average number of knots present in the intertidal mudflats two hours before or after low tide when knots were present (e.g. no censuses with zeros) was 2040 
(=maximum flock size, in 2015). Major threats to red knots are from recreationists, overfishing of horseshoe crabs (reduction in egg prey base), and use of the intertidal by aquaculture. We discuss the role of stakeholders in conservation and protection of red knots.

\section{INTRODUCTION}

Animals have specific habitat requirements that contribute to their survival, reproduction, and longevity. These requirements shift at different times in the life cycle, and differ as a function of age, reproductive stage, and geographical location, among other factors. Habitat use, and foods consumed, may differ at different times of the year, especially for species that migrate between wintering and breeding grounds. The risk animals' face throughout the year often depends upon one or more bottleneck locations where resources (habitat, food) are limited, or where human activities provide a disturbance. This is especially true for long-distance migrants, such as shorebirds that migrate from Arctic or sub-Arctic breeding grounds to the southern hemisphere. During this long-distance flight, shorebirds stop at a very few sites to rest and refuel (gain enough weight to complete the next leg of their journey [1-3]).

For centuries, reproductive success and population levels of most shorebird species were largely influenced by physical (e.g. weather, climate, habitat, water) and biological factors (e.g. presence of food, competitors, cooperators, predators). However, more recently, human activities have become a limiting factor for population stability of some species. Cultural aspects are often ignored in environmental monitoring and assessments of species health, as well as in life history studies. However, human values, perceptions, and activities are increasingly important determiners of a species' survival and population levels [4-6]. Human dimensions are directly affecting shorebirds by decreasing available habitat, decreasing suitable habitat without human disturbance, and decreasing food supplies (by habitat loss, competition, or exposure to contaminants [7-9]), and indirectly by climate change and sea level rise [10,11]. These factors are changing rapidly, especially with increasing populations moving to coastal areas [12] and rising sea levels $[10,11,13]$.

In this paper, we examine some of the factors affecting survival and population levels of red knots (Calidris canutus rufa) stopping over on Delaware Bay, New Jersey, including competing uses of beaches by recreationists, fisherman, and aquaculture. We are especially interested in competing claims for the beach and intertidal habitat that is so critical for foraging red knots. Our objectives are to 1) briefly describe red knot life history, 2) review our work with human disturbance and habitat use by red knots, 3) provide new data on intertidal use of several beaches by red knots and other shorebirds, 4) describe relevant users and stakeholders competing for the same habitat, and 5) discuss how competing claims affect red knot health and well-being along Delaware Bay. This paper particularly reports data and significance of shorebird use of 17 beaches examined in 2015 because it provides a broad picture of intertidal use by shorebirds $[14,15]$. While we discuss these factors with respect to the Cape May peninsula, they are applicable to other shorebirds at many different stopovers in the U.S. and elsewhere.

\section{BACKGROUND}

\subsection{Red Knot Life History}

Red Knots are a medium-size shorebird that breeds in the sub-Arctic, migrates south, some wintering as far south as Tierra del Fuego (30,000 km [16]), although some overwinter along the U.S. Atlantic coast [17]. Red Knots may live 12 - 15 years, but they do not breed until they are 2 - 3 years old [18]. On their way north each spring, a significant portion of the Northern Hemisphere's rufa population migrates through Delaware Bay $[18,19]$. Here they arrive in early May, fat-depleted after a long flight. Facing the constraint of a very short breeding season awaiting them at high latitudes, they have only about two to three weeks to load on sufficient fat for the next multi-thousand kilometer journey to the sub-Arctic breeding grounds where they must arrive with sufficient energy reserve to begin mating and nesting. At 
the Delaware Bay stopover, red knots require 3 major things $[18,19]: 1)$ suitable habitat for roosting, resting, and foraging, 2) adequate prey, and 3) adequate time to feed, free of disturbance by predators, people, dogs, and vehicles (and other disturbances). Each of these major aspects will be described briefly below.

On the Cape May Peninsula, red knots use three types of habitat: marsh, beach, and mudflats [15, 20]. Although over the last 20 years most of the studies on foraging have focused on high tide when shorebirds forage on horseshoe crab eggs, they also forage on intertidal mudflats, the subject of our results presented below, and roost on the high beach or sand bars when not foraging. Suitable habitat includes considerations of space enough to forage, and prey enough for the number of birds present [21]. Adequate prey for foraging knots is a function of prey suitability, prey availability, and space to forage successfully. That is, knots need abundant horseshoe crab eggs [22], the eggs have to be available for capturing (e.g. on the surface or within bill depth), and each knot has to have enough space to successfully capture prey $[15,19,20$, 23]. Red knots have to compete with other shorebirds for both foraging space and prey, in addition to gulls and people $[24,25]$. Human recreation can be a significant contributor to disturbing foraging shorebirds in many places [26].

\subsection{Brief Summary of Our Past Studies}

The threats red knots face are from recreationists, fishing, and aquaculture. Southern New Jersey has a rich ornithological history, starting with Alexander Wilson and Charles Bonaparte who wrote- "On the jersey side of the Delaware Bay, in the neighborhood of Fishing Creek, about the middle of May, the Black-headed Gulls assemble in great multitudes, to feed upon the remains of the King Crabs, which the hogs have left, or upon the spawn, which those curious animals deposit in the sand" [27]. The "Blackheaded Gulls" referred to are actually Laughing Gulls, and the "King Crabs" are Horseshoe Crabs. In the past, shorebirds had to deal with market gunning [27]; knots were especially prized, and "they decoy with ease" [28]). In the early 1900s, horseshoe crabs were exploited for fertilizer, resulting in a crash in number of horseshoe crab eggs [29].

People did not flock to the shore until after the Second World War when insecticides became available and were used to kill large number of mosquitoes that bred in the salt marshes. With the influx of people came housing, marinas, and industries, and the number of people on beaches increased. In several studies with recreational activity, we have shown that 1) shorebirds (including knots) are disturbed by the presence of people, and return to the beach less frequently and at longer intervals than gulls that compete for the crab eggs, 2) shorebirds were more disturbed by dogs than by people, 3) experiments with closure of a beach indicated that when people are present knots move to a protected fenced-off area, but when it is closed they use the entire beach for foraging [30] and 4) voluntary closure of a beach is not as effective as mandatory closure in protecting foraging shorebirds [31].

Protecting the knot's prey source (crab eggs) is an on-going process. Fishing (removal of horseshoe crabs for bait) was a process that took many years, but has resulted in control by the Atlantic States Marine Fisheries Commission (see below) writing a management plan that took into account the needs of foraging shorebirds, and limited the take of horseshoe crabs (particularly females [32]).

The newest threat to shorebird (and red knot well-being) is the desire to increase intertidal aquaculture on the New Jersey side of Delaware Bay, into some of the prime shorebird (and red knot) foraging habitat. The question of aquaculture is complicated because several issues must be addressed, including 1) do shorebirds feed in the intertidal mudflat where oyster racks would be placed, 2) is the intertidal important to foraging shorebirds, including red knots, 3) are the shorebirds (and knots) disturbed by the presence of oyster racks, and/or the activities of the oyster workers in the intertidal, and/or on the beaches, and 4) how can these issues be addressed. Observations of responses of red knots and other shorebirds to an experimentally-constructed rack and bag oyster culture set up (with oysters) indicated that knots were most affected by people, followed by tide, and virtually no red knots were present near oyster racks when aquaculture workers or recreational beach-users were on the beach [33]. This experiment, however, was confounded by the potential presence of recreationists on the beach and oyster workers. To partly address 
this, in 2016 we constructed oyster racks and reefs (along with a control), without any oyster worker activity. The mean number of red knots/census was 13 for racks and over 68 for the sections with reefs and a control (highly significant). Treatment, date, and number of non-knot shorebirds explained 69\% of the variance in number of red knots foraging in each section (racks, reefs, control [34]).

Like many other shorebirds, in most places red knots forage on mudflats or saltflats, as well as on the inner and outer beach. Red knot forage in all three of these habitats during fall migration along the Atlantic coast of New Jersey, although they concentrate on the mudflats [15]. In a study in Cape May that included Delaware Bay and Atlantic coastal beaches and marshes, 69\% of the shorebirds we found during censuses $(\mathrm{N}=1442$ censuses, equal among habitat types) foraged on mudflats [20]. For red knots, 85\% were on intertidal mudflats, and $60 \%$ of the variation in the percent of knots foraging was explained by location, followed by time of day and location X tide [20]. In that study, a higher percentage of red knots fed during rising tides (59\%) than at other tide times. In these and other foraging studies, specific details of where exactly the knots fed (relative to the high tide and low tide lines) were not clear. At Reed's Beach (one of the key shorebird foraging sites), only half as many knots fed on the beach mud as fed at the tide line. In other words, several years ago, there were two-thirds of the shorebirds on the beach (high tide line) and the other third fed on the mudflat. This information is critical when considering the competing claims of aquaculture and shorebirds using the same mudflats. While over $30 \%$ of the birds counted were foraging on the intertidal mudflat compared to those concentrated at the high tide line, one key question is where on the intertidal do they feed (e.g. close to the high tide line, $50 \mathrm{~m}$ out in the intertidal, or even farther out?).

\section{APPROACH AND METHODS}

Our overall approach is to 1) provide new data on intertidal habitat use by shorebirds and red knots, 2) enumerate competing claims to their habitat, 3) list the stakeholders whose actions affect red knot use of habitat during their stopover on Delaware Bay, and 4) discuss the implications of the aforementioned aspects that directly affect survival and population viability of the rufa population of red knots. Thus we reviewed our previous studies with red knot habitat use (see above), and present new data on red knot habitat use of the intertidal.

We counted shorebirds at different times of day (reflecting different times in the tide cycle) in 2015 and 2016. In 2015 we conducted an extensive study of several beaches along the New Jersey shore of De-

laware Bay $(\mathrm{N}=17)$, and in 2016 we conducted an intensive study of 5 beaches that were also included in the 2015 study. We observed shorebirds on all the beaches from Villas to Money Island in 2015 and at 5 in 2016 that all had at least $300 \mathrm{~m}$ of intertidal flats at very low tides (Figure 1). Shorebirds fed on the eggs of horseshoe crabs (Limulus polyphemus) in the surf and sand; as the tide receded they fed on the eggs scattered on the mud. We recorded the number of total shorebirds and number of red knots) at three distances $(0-100 \mathrm{~m}, 101$ to $200 \mathrm{~m}, 201$ to $300 \mathrm{~m})$ from the mean high tide, in a $300 \mathrm{~m}$ stretch of beach. Data were not recorded for the $30 \mathrm{~min}$ around high tide as the birds were concentrated at the tidal edge (rather than on the intertidal mudflats).

The data reported in this paper is based on 225 censuses in 2015 and 683 censuses in 2016 at different tide times. The number of censuses was not evenly distributed among beaches in 2015; we attempted to visit each beach from 1 to 8 times during low tide, but there were more censuses at Dias Creek, where oyster racks were deployed. At the time of data collection, we recorded the time of day, and the number of total shorebirds (and knots) present, by location. Other species present were ruddy turnstone (Arenaria interpres), semipalmated sandpiper (Calidris pusilla), sanderling (Calidris alba), and dunlin (Calidris alpina). We later assigned tide time from tide charts as it was difficult to assess in the field. Any census taken from the time of low tide to 1 hour after was assigned to the $1 \mathrm{hr}$ group, and so on. In 2015, 8 people recorded the number of birds present by tide time, recording the data whenever they checked the beaches to determine where along this stretch of Delaware Bay shorebirds were present. In 2016 three observers were present all day at a given beach, shifting among beaches to achieve equal sample sizes, although the 2016 


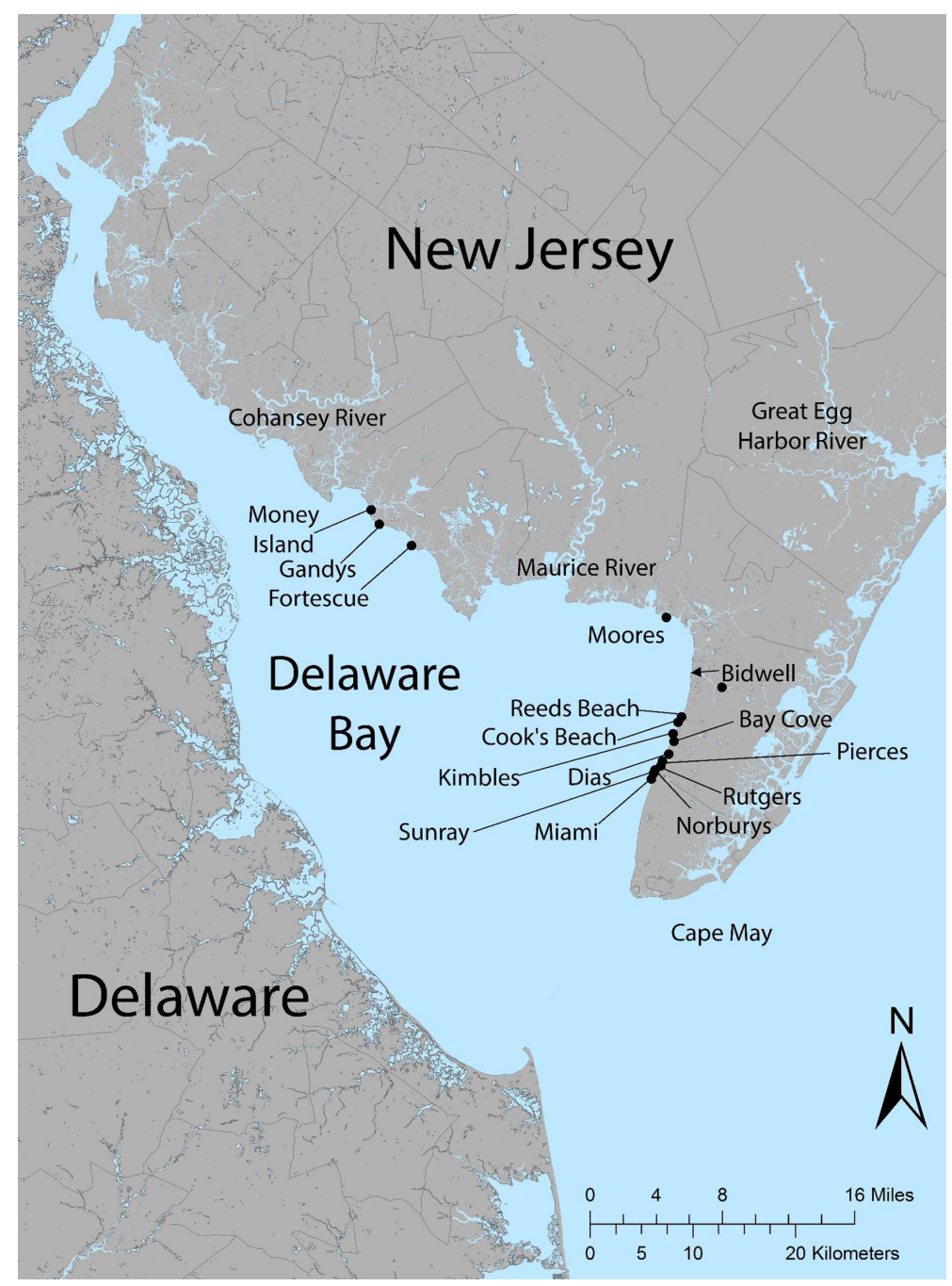

Figure 1. Map of the New Jersey side of Delaware Bay (New Jersey) with the sites where shorebirds (and Red Knots) were studied in 2015 and 2016. GPS coordinates of Delaware Bay study sites are approximately N39.096 W74.905.

data is not the main emphasis of this paper.

We provide three methods of examining shorebird use of the intertidal: 1) the percent of censuses when any shorebirds (or knots) was in the intertidal out to $300 \mathrm{~m}, 2$ ) the average number of shorebirds present by tide time (hours since low tide)/census and 3) the average number of red knots present when any shorebirds were present/census. We computed the latter because red knots usually avoid areas where no other shorebirds are feeding.

We also present data on the 4 northern beaches (Moore's, Money Island, Fortescue, Gandys) in one of the 2015 tables, but do not include them in the graphs or statistical analyses because they are farther north, somewhat protected from human disturbance by their inaccessibility, are partly protected from predators by water around slightly elevated sandbars, and the intertidal is not longitudinal along the shore. These beaches are often used more for roosting by shorebirds than for foraging. Data were analyzed using the Kruskal Wallis $\mathrm{X}^{2}$ test (PROC NPARIWAY [35]). We used these non-parametric tests because they are more conservative and are best fitted for small datasets $[14,36]$. We also developed a model to understand 
the factors contributing to the number of red knots present in 2015 (PROC, GLM [14]). Further descriptions of methods (and related studies) can be found in Burger and Niles [37, 38].

\section{RESULTS}

\subsection{Field Studies and Analysis}

The decline of the rufa red knot has led to considerable interest in the factors that affect their survival and reproduction, especially those that affect whether they are able to gain enough weight to successfully reach their Arctic breeding grounds with sufficient resources to nest successfully. The expansion of aquaculture into the intertidal could pose a severe risk for foraging red knots. Basic to understanding the conflict is determining how red knots and other shorebirds use the intertidal. In 2015 and 2016 we examined this question, first for a number of beaches (2015, Figure 1), and then for the 5 key beaches (2016, see methods).

In 2015 we examined two types of beaches: those used primarily for foraging, and those used mainly for roosting, with some foraging. One of the difficulties with most surveys of shorebirds is that the data contain a lot of zeros (i.e. no shorebirds present on a particular beach during a particular survey). This was not the case for our data (Figure 2, Table 1 and Table 2). For the roosting/foraging beaches (Money Island, Gandy's, Fortescue and Moore's), shorebirds (and red knots) were found over $88 \%$ of the time. For foraging beaches in 2015 , shorebirds were found on $85 \%$ of the surveys, and knots were found on $48 \%$ of the surveys. In 2016 shorebirds were found on $95 \%$ of the surveys, and knots were found on nearly $70 \%$ of the surveys (Figure 2). This difference was due to the number of beaches surveyed. In 2015 we surveyed 13 longitudinal beaches, while in 2016 we selected 5 beaches that had at least a $250 \mathrm{~m}$ intertidal extent (at low tide) area. The best model (PROC, GLM [14]) for the number of red knots counted/census in 2015 explained $51 \%$ of the variability $(\mathrm{F}=4.14, \mathrm{P}<0.0001)$ in terms of number of non-knots (=other shorebirds) present $(\mathrm{F}=52, \mathrm{P}<0.0001)$, location $(\mathrm{F}=5, \mathrm{P}<0.0001)$, tide time $(\mathrm{F}=2.4, \mathrm{P}<0.007)$ and date $(\mathrm{F}=1.94$, $\mathrm{P}<0.02)$.

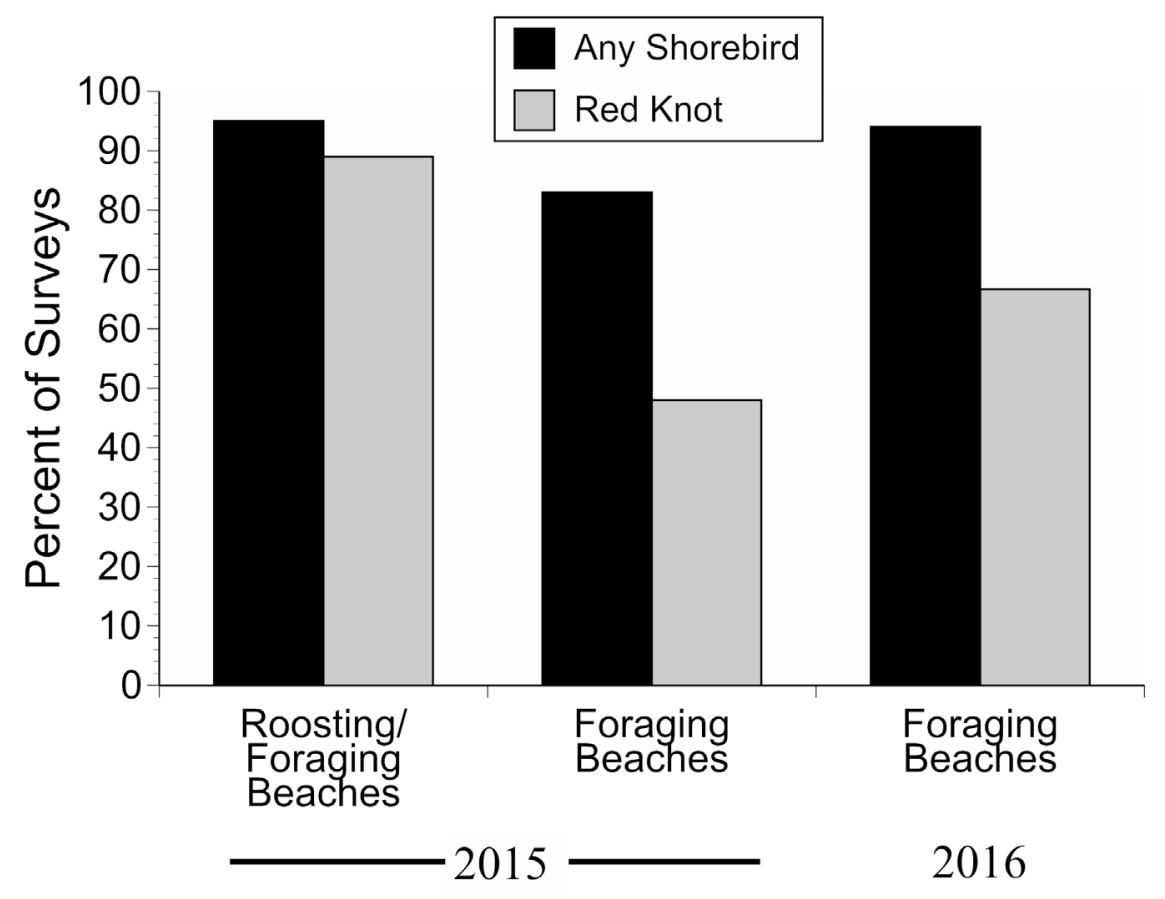

Figure 2. Percent of surveys with some shorebirds (and Red Knots) present in 2015 and 2016 for studies on Delaware Bays. 
Table 1. Number of all species of shorebird present $0-300 \mathrm{~m}$ area perpendicular to mean high tide in 2015. Shown is the mean number of shorebirds present in different intertidal zones by location. Given are mean \pm SE.

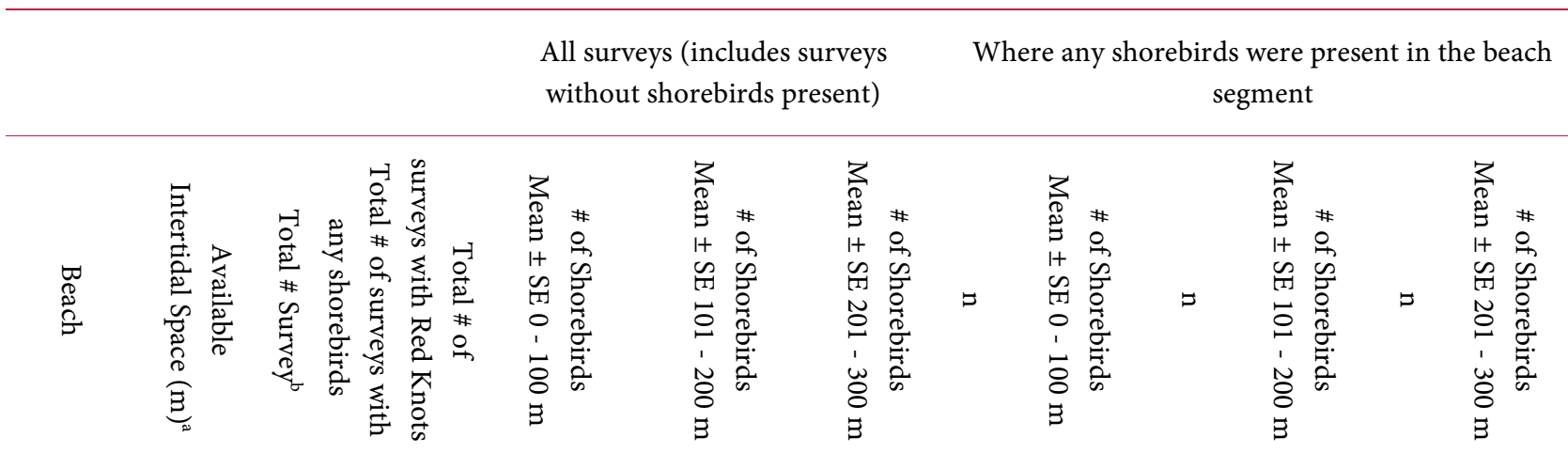

Roosting \& Feeding Sites ${ }^{\mathrm{d}}$

$\begin{array}{cccccccccccc}\begin{array}{c}\text { Money } \\ \text { Island }\end{array} & 80 & 3 & 2 & 2 & 873 \pm 440 & 0 \pm 0 & 0 \pm 0 & 2 & 1310 \pm 90 & & \\ \text { Gandy's } & 105 & 4 & 4 & 4 & 4042 \pm 2260 & 313 \pm 313 & 0 \pm 0 & 4 & 4042 \pm 2260 & 1 & 1250 \pm . \\ \text { Fortescue } & 148 & 9 & 9 & 8 & 4994 \pm 1521 & 2286 \pm 1097 & 0 \pm 0 & 8 & 5619 \pm 1573 & 4 & 5143 \pm 1522 \\ \text { Moore's } & 306 & 3 & 3 & 3 & 3640 \pm 1618 & 370 \pm 370 & 33 \pm 33 & 3 & 3640 \pm 1618 & 1 & 1110 \pm . \\ \end{array}$

Feeding Sites

\begin{tabular}{|c|c|c|c|c|c|c|c|c|c|c|c|c|c|}
\hline $\begin{array}{c}\text { Bidwell } \\
\text { Creek }\end{array}$ & 105 & 1 & 1 & 1 & 45 & 0 & 0 & 1 & 45 & & & & \\
\hline $\begin{array}{l}\text { Reed's } \\
\text { North }\end{array}$ & 37 & 11 & 4 & 2 & $165 \pm 96.5$ & $0 \pm 0$ & $0 \pm 0$ & 4 & $453 \pm 205$ & & & & \\
\hline $\begin{array}{l}\text { Reed's } \\
\text { South }\end{array}$ & 190 & 22 & 12 & 9 & $764 \pm 262$ & $711 \pm 271$ & $37 \pm 35$ & 11 & $1527 \pm 415$ & 9 & $1737 \pm 498$ & 2 & $4 \pm 357$ \\
\hline Cook's & 190 & 30 & 23 & 19 & $915 \pm 269$ & $242 \pm 99.4$ & $0 \pm 0$ & 23 & $1194 \pm 331$ & 7 & $1036 \pm 260$ & & \\
\hline Kimble's & 131 & 15 & 9 & 7 & $115 \pm 45.8$ & $45.3 \pm 30.7$ & $0 \pm 0$ & 7 & $246 \pm 71.5$ & 3 & $227 \pm 112$ & & \\
\hline Bay Cove & 106 & 15 & 14 & 12 & $926 \pm 420$ & $243 \pm 118$ & $0 \pm 0$ & 11 & $1262 \pm 542$ & 6 & $607 \pm 231$ & & \\
\hline Dias & 249 & 51 & 50 & 24 & $18.7 \pm 3.7$ & $36.5 \pm 5.3$ & $9.5 \pm 2.8$ & 34 & $28.1 \pm 4.8$ & 43 & $43.2 \pm 5.7$ & 17 & $28 \pm 6.4$ \\
\hline Pierces & 216 & 22 & 22 & 16 & $521 \pm 147$ & $157 \pm 51$ & $113 \pm 61$ & 19 & $604 \pm 162$ & 11 & $315 \pm 77.3$ & 6 & $414 \pm 181$ \\
\hline Rutgers & 329 & 3 & 1 & 0 & $0 \pm 0$ & $0 \pm 0$ & $25 \pm 25$ & 0 & & & & 1 & 75 \\
\hline Norbury's & 352 & 13 & 13 & 6 & $162 \pm 76.4$ & $246 \pm 113$ & $159 \pm 80$ & 8 & $263 \pm 112$ & 7 & $456 \pm 177$ & 7 & $295 \pm 130$ \\
\hline $\begin{array}{l}\text { Sunray } \\
\text { Beach }\end{array}$ & 298 & 1 & 1 & 0 & 450 & 0 & 0 & 1 & 450 & & & & \\
\hline $\begin{array}{c}\text { Delaware } \\
\text { Ave }\end{array}$ & 305 & 5 & 4 & 0 & $24.8 \pm 15.2$ & $75 \pm 70.6$ & $60 \pm 39$ & 3 & $41.3 \pm 20.7$ & 2 & $188 \pm 170$ & 2 & $150 \pm 42$ \\
\hline Villas & $132-302$ & 27 & 26 & 7 & $253 \pm 73.9$ & $128 \pm 41.3$ & $201 \pm 93$ & 23 & $297 \pm 83.6$ & 16 & $216 \pm 61.1$ & 12 & $452 \pm 189$ \\
\hline
\end{tabular}

a. 2013 DEP Natural Color Imagery (Jul. 16, 2013, aerial imagery flown within $+/-1.5$ hrs. of low tide, (https://njgin.state.nj.us/oit/gis/NJ_NJGINExplorer/wms_instruct.htm). Predicted low $+0.21 \mathrm{ft}$. at Bidwell Creek Entrance Station ID 8536581) (Source Amanda Dey, 2016). b. On any survey, birds could be counted on all 3 segments if they were there. c. In these data if any shorebird was present in the $0-300 \mathrm{~m}$ transect it was included. d. Not standardized to $300 \mathrm{~m}$ along beach. 
Table 2. Location of Red Knots in the $0-300 \mathrm{~m}$ area perpendicular to mean high tide (2015). Given are mean $\pm \mathrm{SE}$.

\begin{tabular}{|c|c|c|c|c|c|c|c|c|c|c|c|c|c|}
\hline \multirow[b]{2}{*}{ 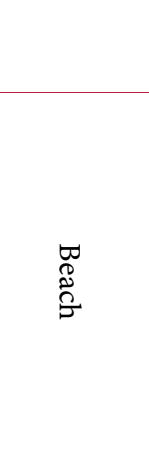 } & \multirow[b]{2}{*}{ 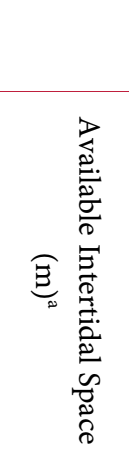 } & \multirow[b]{2}{*}{ 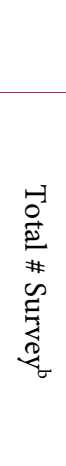 } & \multirow[b]{2}{*}{ 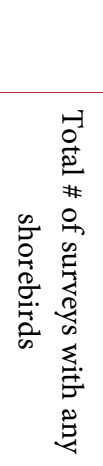 } & \multirow[b]{2}{*}{ 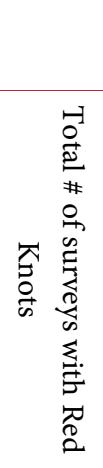 } & \multicolumn{3}{|c|}{$\begin{array}{l}\text { Where any shorebird was present } \\
\text { in any beach segment }{ }^{c}\end{array}$} & \multicolumn{6}{|c|}{$\begin{array}{l}\text { Where red knots were present in the } \\
\text { beach segment }\end{array}$} \\
\hline & & & & & 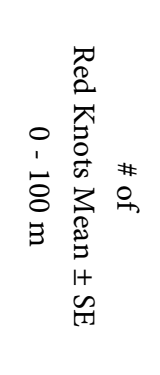 & 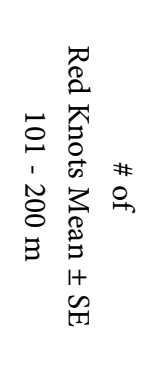 & 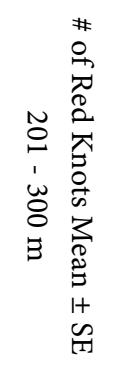 & $=$ & 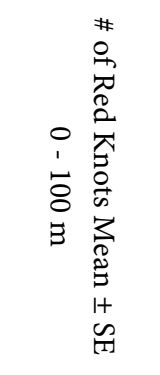 & $F$ & 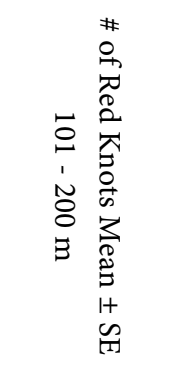 & $=$ & 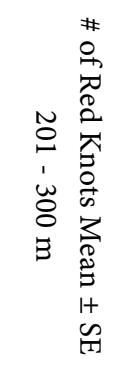 \\
\hline $\begin{array}{l}\text { Roosting } \\
\text { \& Feeding } \\
\text { Sites }^{\mathrm{d}}\end{array}$ & & & & & & & & & & & & & \\
\hline $\begin{array}{l}\text { Money } \\
\text { Island }\end{array}$ & 80 & 3 & 2 & 2 & $500 \pm 289$ & & & 2 & $750 \pm 250$ & & & & \\
\hline Gandy's & 105 & 4 & 4 & 4 & $670 \pm 439$ & & & 4 & $670 \pm 439$ & & & & \\
\hline Fortescue & 148 & 9 & 9 & 8 & $844 \pm 386$ & $778 \pm 544$ & & 7 & $1086 \pm 460$ & 4 & $1750 \pm 1100$ & & \\
\hline $\begin{array}{l}\text { Moore's } \\
\text { Feeding } \\
\text { Sites } \\
\mathrm{N} \text { of }\end{array}$ & 306 & 3 & 3 & 3 & $300 \pm 100$ & $67 \pm 67$ & $0 \pm 0$ & 3 & $300 \pm 100$ & 1 & 200 & & \\
\hline $\begin{array}{l}\text { Bidwell } \\
\text { Creek }\end{array}$ & 105 & 1 & 1 & 1 & 5 & 0 & 0 & 1 & 5 & & & & \\
\hline $\begin{array}{l}\text { Reed's } \\
\text { North }\end{array}$ & 37 & 11 & 4 & 2 & $20.7 \pm 19$ & $\begin{array}{l}0 \\
0\end{array}$ & $\begin{array}{l}0 \\
0\end{array}$ & 2 & $114 \pm 96$ & & & & \\
\hline $\begin{array}{l}\text { Reed's } \\
\text { South }\end{array}$ & 190 & 22 & 12 & 9 & $126 \pm 43.8$ & $266 \pm 99.2$ & $11 \pm 9.8$ & 7 & $396 \pm 57.2$ & 8 & $731 \pm 181$ & 2 & $121 \pm 95$ \\
\hline Cook's & 190 & 30 & 23 & 19 & $354 \pm 116$ & $160 \pm 81.1$ & $\begin{array}{l}0 \\
0\end{array}$ & 19 & $559 \pm 168$ & 7 & $684 \pm 276$ & & \\
\hline Kimble's & 131 & 15 & 9 & 7 & $54.5 \pm 23.6$ & $28.1 \pm 24.6$ & $\begin{array}{l}0 \\
0\end{array}$ & 6 & $136 \pm 40.8$ & 2 & $211 \pm 158$ & & \\
\hline Bay Cove & 106 & 15 & 14 & 12 & $711 \pm 403$ & $151 \pm 71.8$ & $\begin{array}{l}0 \\
0\end{array}$ & 9 & $1184 \pm 635$ & 5 & $454 \pm 140$ & & \\
\hline Dias & 249 & 51 & 50 & 24 & $4.7 \pm 1.8$ & $4.4 \pm 1.8$ & $1.7 \pm 0.8$ & 14 & $17.1 \pm 5.4$ & 16 & $13.9 \pm 5.2$ & 6 & $15 \pm 3.7$ \\
\hline Pierces & 216 & 22 & 22 & 16 & $164 \pm 69.5$ & $39.8 \pm 22.5$ & $31 \pm 16$ & 9 & $400 \pm 138$ & 6 & $146 \pm 68.4$ & 6 & $115 \pm 47$ \\
\hline Rutgers & 329 & 3 & 1 & 0 & $0 \pm 0$ & $0 \pm 0$ & $0 \pm 0$ & & & & & & \\
\hline Norbury's & 352 & 13 & 13 & 6 & $1.8 \pm 1.7$ & $49 \pm 19.1$ & $41 \pm 32$ & 2 & $12 \pm 10.5$ & 5 & $128 \pm 18.2$ & 3 & $179 \pm 121$ \\
\hline $\begin{array}{l}\text { Sunray } \\
\text { Beach }\end{array}$ & 298 & 1 & 1 & 0 & 0 & 0 & 0 & & & & & & \\
\hline $\begin{array}{l}\text { Delaware } \\
\text { Ave }\end{array}$ & 305 & 5 & 4 & 0 & $0 \pm 0$ & $0 \pm 0$ & $0 \pm 0$ & & & & & & \\
\hline Villas & $132-302$ & 27 & 26 & 7 & $7.4 \pm 6.9$ & $14 \pm 13.9$ & $56 \pm 56$ & 2 & $99.4 \pm 88.1$ & 3 & $126 \pm 124$ & 3 & $502 \pm 499$ \\
\hline
\end{tabular}

a. 2013 DEP Natural Color Imagery (Jul. 16, 2013, aerial imagery flown within $+/-1.5$ hrs. of low tide, (https://njgin.state.nj.us/oit/gis/NJ_NJGINExplorer/wms_instruct.htm). Predicted low $+0.21 \mathrm{ft}$. at Bidwell Creek Entrance Station ID 8536581) (Source Amanda Dey, 2016). b. On any survey, birds could be counted on all 3 segments if they were there. $c$. In these data if any shorebird was present in the $0-300 \mathrm{~m}$ transect it was included. $\mathrm{d}$. Not standardized to $300 \mathrm{~m}$ along beach. 
Since NJ regulations currently require aquaculture to be at least 300 feet from the mean high tide line, it is important to know exactly where the shorebirds and knots are foraging. The location of all shorebirds (Table 1) and red knots (Table 2) indicate great variability among locations in where shorebirds are located. For example, much larger numbers of shorebirds (and knots) were located at the northern, non-longitudinal beaches than on the 13 longitudinal beaches because these beaches were used for BOTH roosting and foraging (2015). Further a few of the longitudinal beaches had almost no shorebirds (e.g. N. of Bidwell Creek, Rutgers), and others had much higher numbers (e.g. Cook's, Bay Cove). Since our study at each beach included only a section that was $300 \mathrm{~m}$ long along the beach (to allow direct comparison among beaches), the numbers of shorebirds on these beaches was often greater, i.e. part of the flock was outside of our count area.

Tide is obviously an important factor affecting number of birds foraging and the location of foraging. The pattern of all shorebirds foraging in 2015 (for the extensive survey of 13 longitudinal beaches) varied by tide time (Figure 3, note difference in scale). Shorebirds generally moved farther out from the mean high tide line as the tide receded, until there were peak numbers in the $100-200 \mathrm{~m}$ section in the hour be-

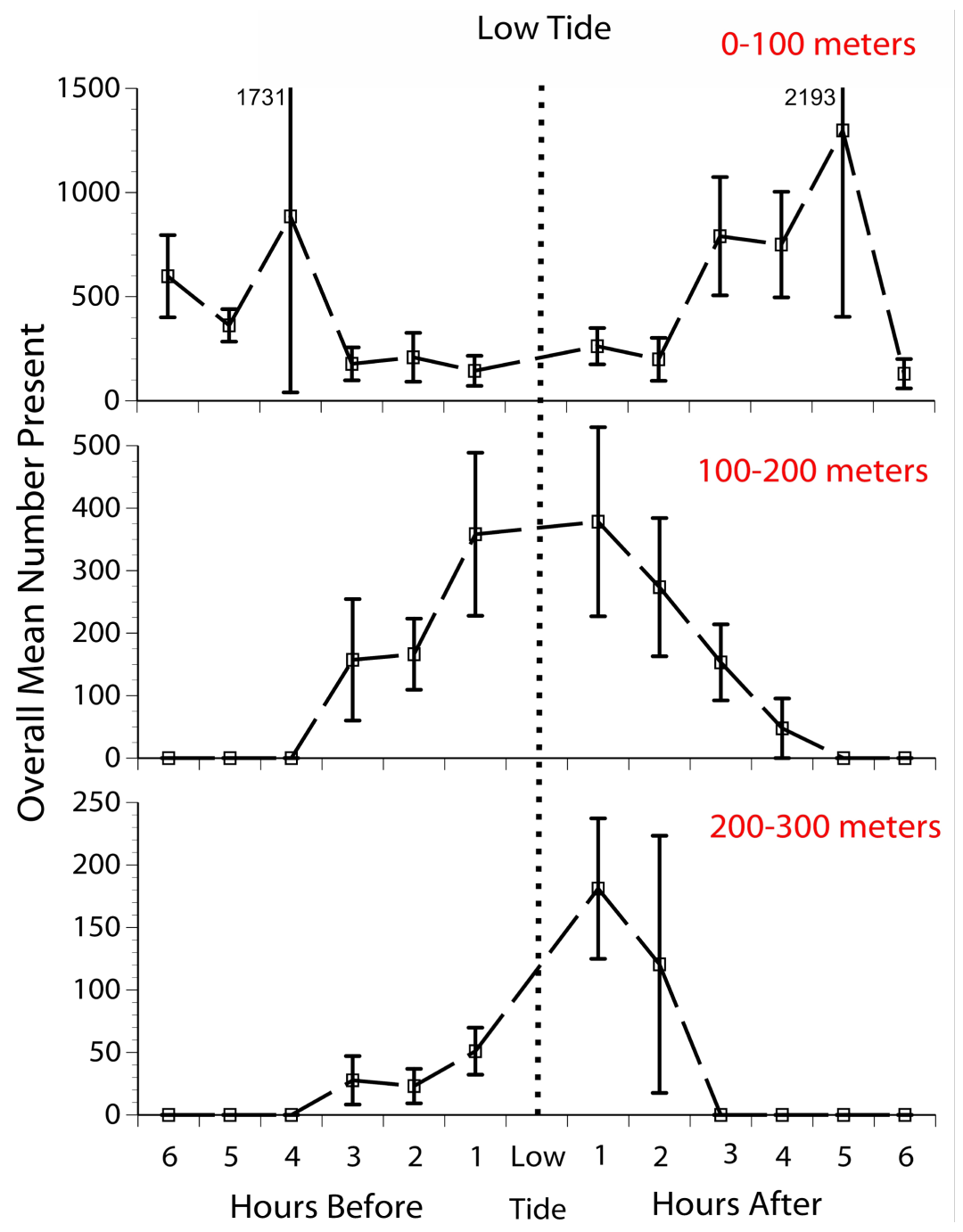

Figure 3. Mean number of shorebirds/census as a function of tide and location on the intertidal mudflat in 2015 (distances were 0 - $100 \mathrm{~m}$ from the mean high tide, $101-200 \mathrm{~m}$, and 201 $300 \mathrm{~m}$ from mean high tide). 
fore and after low tide. As the tide receded further, some shorebirds moved into the $200-300 \mathrm{~m}$ section (although more remained in the 100 - $200 \mathrm{~m}$ section (others remained in the $100-200 \mathrm{~m}$ section, Figure 3)). The lower numbers in the $200+\mathrm{m}$ section partly reflect variations in tide height, some days this section was never exposed, giving rise to lower means than if we could perfectly measure how much of the 201 - $300 \mathrm{~m}$ from mean high tide section was exposed.

Like total numbers of shorebirds, Red knots numbers were affected by tide time, and shifted location with the changing tides (Figure 4, Table 3). In the study of 13 longitudinal beaches (2015), red knot numbers were highest 3 - 4 hours before low tide in the $0-100 \mathrm{~m}$ section, were highest in the $101-200 \mathrm{~m}$ section from three hours before low tide to one hour after, and were highest in the $201-300 \mathrm{~m}$ section in the hour before and hour after low tide. Knots appeared not to forage as much on the longitudinal beaches in the 4 - 5 hours after low (about 2 hours before high), perhaps because they had fed extensively on the intertidal, and were digesting eggs prior to feeding on the masses of eggs at the high tide line where the

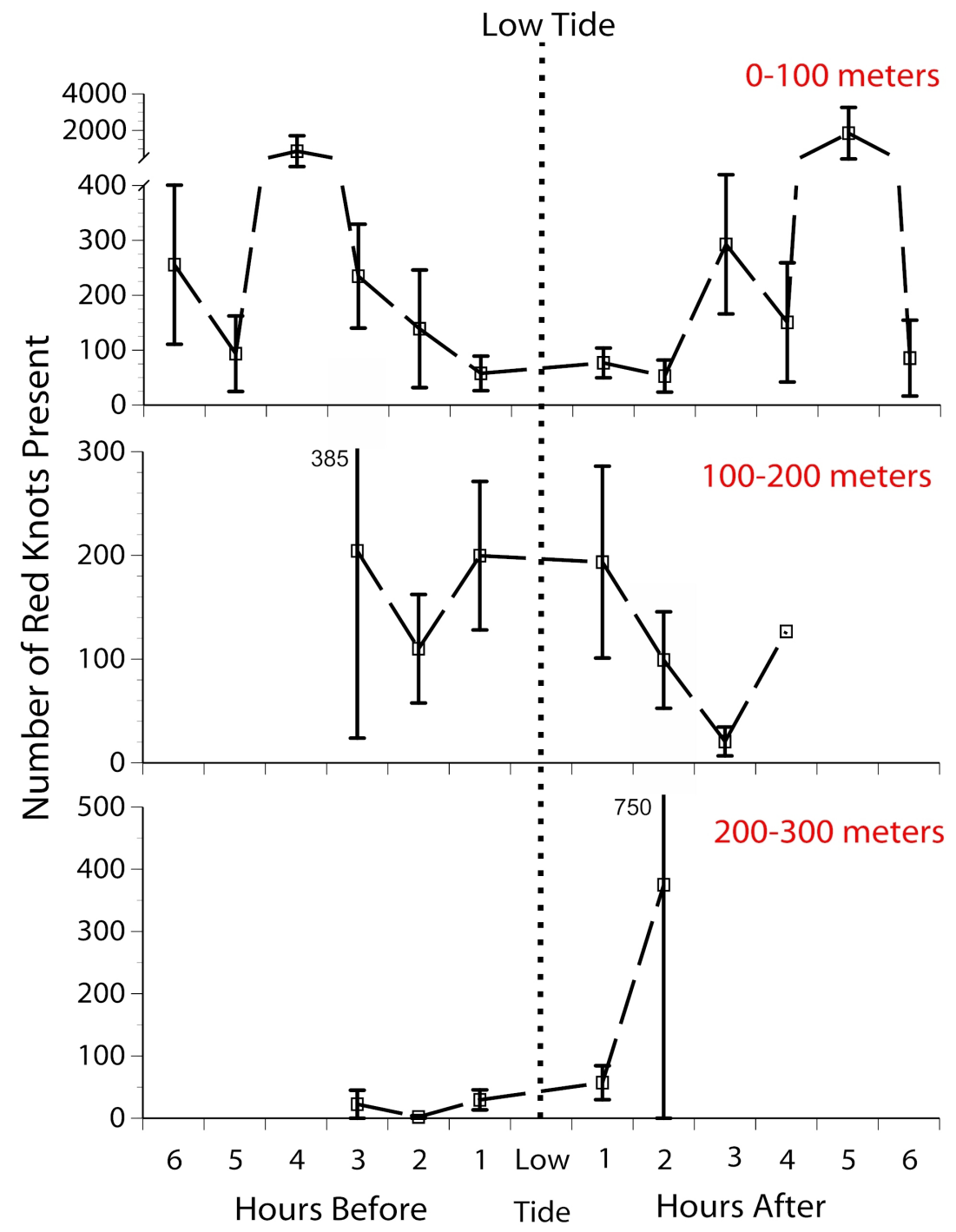

Figure 4. Mean number of Red Knots/census as a function of tide and location on the intertidal mudflat in 2015 (distances were $0-100 \mathrm{~m}, 101-200 \mathrm{~m}$, and $201-300 \mathrm{~m}, 2015$ from mean high tide). 
Table 3. Mean number of red knots present in different intertidal zones relative to low tide when aquaculture workers also have access to their oysters on racks. Includes beaches from Villas north to Bidwell Creek. Excludes Fortescue, Gandy's, Money Island, and Moore's.

\begin{tabular}{|c|c|c|c|c|c|c|c|c|}
\hline \multicolumn{6}{|c|}{$\begin{array}{l}\text { Intertidal Time relative Total \# Where any shorebird was present } \\
\text { section to low tide survey }{ }^{\mathrm{a}} \text { in the beach segment }{ }^{\mathrm{b}}\end{array}$} & \multicolumn{3}{|c|}{$\begin{array}{l}\text { Where red knots were } \\
\text { present in the beach segment }{ }^{\mathrm{b}}\end{array}$} \\
\hline & & & $\mathrm{n}$ & Mean + SE & $\operatorname{Max}$ & $\mathrm{n}$ & Mean + SE & $\operatorname{Max}$ \\
\hline \multirow[t]{4}{*}{$\begin{array}{l}0 \text { to } 100 \\
\mathrm{~m}\end{array}$} & $\begin{array}{l}1 \text { to } 2 \text { hours } \\
\text { before }\end{array}$ & 22 & 16 & $138.9 \pm 107.1$ & 1700 & 5 & $444.6 \pm 321.9$ & 1700 \\
\hline & $\begin{array}{l}0 \text { to } 1 \text { hour } \\
\text { before }\end{array}$ & 28 & 19 & $57.7 \pm 31.5$ & 425 & 7 & $156.6 \pm 74$ & 425 \\
\hline & $\begin{array}{l}0 \text { to } 1 \text { hour } \\
\text { after }\end{array}$ & 37 & 26 & $76.8 \pm 27.1$ & 420 & 10 & $199.8 \pm 50.8$ & 420 \\
\hline & $\begin{array}{l}1 \text { to } 2 \text { hours } \\
\text { after }\end{array}$ & 22 & 14 & $52.8 \pm 29.1$ & 360 & 9 & $82.2 \pm 43$ & 360 \\
\hline \multirow[t]{4}{*}{$\begin{array}{l}101 \text { to } \\
200 \mathrm{~m}\end{array}$} & $\begin{array}{l}1 \text { to } 2 \text { hours } \\
\text { before }\end{array}$ & 22 & 19 & $110 \pm 52.3$ & 850 & 9 & $232.2 \pm 97.1$ & 850 \\
\hline & $\begin{array}{l}0 \text { to } 1 \text { hour } \\
\text { before }\end{array}$ & 28 & 23 & $199.7 \pm 71.6$ & 1200 & 13 & $353.4 \pm 110.1$ & 1200 \\
\hline & $\begin{array}{l}0 \text { to } 1 \text { hour } \\
\text { after }\end{array}$ & 37 & 29 & $193.5 \pm 92.5$ & 2040 & 12 & $467.7 \pm 202.4$ & 2040 \\
\hline & $\begin{array}{l}1 \text { to } 2 \text { hours } \\
\text { after }\end{array}$ & 22 & 16 & $99.1 \pm 46.5$ & 540 & 9 & $176.2 \pm 74.3$ & 540 \\
\hline \multirow[t]{4}{*}{$\begin{array}{l}201 \text { to } \\
300 \mathrm{~m}^{\mathrm{c}}\end{array}$} & $\begin{array}{l}1 \text { to } 2 \text { hours } \\
\text { before }\end{array}$ & 22 & 8 & $2.1 \pm 1.9$ & 15 & 2 & $8.3 \pm 6.8$ & 15 \\
\hline & $\begin{array}{l}0 \text { to } 1 \text { hour } \\
\text { before }\end{array}$ & 28 & 14 & $29.5 \pm 16.1$ & 210 & 7 & $59.1 \pm 29$ & 210 \\
\hline & $\begin{array}{l}0 \text { to } 1 \text { hour } \\
\text { after }\end{array}$ & 37 & 19 & $57.1 \pm 27.3$ & 412.5 & 9 & $120.6 \pm 50.8$ & 412.5 \\
\hline & $\begin{array}{c}1 \text { to } 2 \text { hours } \\
\text { after }\end{array}$ & 22 & 4 & $375 \pm 375$ & 1500 & 1 & 1500 & 1500 \\
\hline
\end{tabular}

a. Surveyor could survey all segments at the same time (e.g. 0 - 100, $101-200,201-300)$. b. Relates only to $0-100 \mathrm{~m}, 101-200 \mathrm{~m}$ or $201-300 \mathrm{~m}$. c. Small sample is due to there being few beaches with $201-300 \mathrm{~m}$ intertidal exposed. $\mathrm{d}$. Data has been standardized to $300 \mathrm{~m}$ along beach.

crabs will be spawning. In 2016 (5 beaches study), the mean numbers of shorebirds were generally lower, and the number feeding in the intertidal mudflats $100-201 \mathrm{~m}$ from the mean high tide peaked in the hour before low tide (the hour before low tide include $60 \mathrm{~min}$ to the low tide). However, in the $201-300 \mathrm{~m} \mathrm{sec}-$ tion, the number of shorebirds/census peaked after low tide in 2015, but peaked before low tide in 2015. These differences may reflect differences in egg availability, that the tide did not fall as quickly in 2015 (so they fed earlier), or that less foraging habitat was available in 2016 (e.g. maybe the low tides were not as low). 


\subsection{Discussion}

This study identified two key differences that affected the results: 1) there were longitudinal beaches (straight line with associated mudflat) and there were beaches around creeks or sandy spits that were not longitudinal, that also had a number of exposed sandbars surrounded by water that provided safe roosting areas, 2) There were differences in tidal patterns that affected the spatial extent of intertidal mudflat exposure. Some beaches simply did not have as extensive a mudflat (these beaches had a sharper slope leading into the water). Thus a small difference in tidal height could affect the spatial exposure of the mudflat. This hourly and daily variation was difficult to incorporate.

The mean number of shorebirds (and red knots) present per census varied by location (beach), date and tide time. There were differences in date because shorebirds start arriving in Delaware Bay around the $8-10^{\text {th }}$ of May, and peak in late May (25-29 $9^{\text {th }}$ May). Shorebird (and knot) numbers also varied markedly by beach location. Some beaches had none, others had large flocks. The beach with almost no shorebirds (and no knots) was Rutgers, which has had aquaculture for many years. The beaches with the most birds were near creeks. Shorebirds (and knots) concentrate on beaches near creeks because the beaches are wider, there are protected shoals to roost at very high tides, and the creek mouths themselves provide more ample space for horseshoe crabs to spawn (thus more egg availability). Further, the creek provides protection from heavy surf and winds.

As might be expected, shorebirds move farther out on the mudflat as it is uncovered by the receding tide. In this case, it may be a result of horseshoe eggs (which float) floating out with the tide and being left on the mud as the tide recedes, or has recently been suggested, spawning (and availability of eggs) from females nesting on the shoals. Shorebird numbers declined on the intertidal mudflats with distance from the high tide line. The actual time that the numbers of shorebirds peaked in each section varied somewhat among the years: They peaked before low tide in both 2015 and 2016 in the $101-200 \mathrm{~m}$ section. However, in 2016 they peaked in the $201-300 \mathrm{~m}$ section before low tide, but in 2015 , they peaked in this section after low tide.

Finally, the data clearly show inter-year agreement in a general pattern for shorebirds: 1 ) they use the intertidal for foraging, 2) the timing of peak use for each intertidal section $(0-100 \mathrm{~m}, 101-200,201-300$ $\mathrm{m}$ ) varied among years, and 3) There were differences in the mean numbers/census for the two years (there were more birds in 2015). Red Knot showed similar patterns, although there was great variation among censuses.

\subsection{Methodological Issues}

Shorebird surveys are very complicated because shorebirds flock, and they must follow a shifting food resource, during a tide cycle that changes during the month. Thus, on any given day, at any given time or tide stage, the birds could use any beach or tidal mudflat (partly dependent upon prey availability, wind and wave conditions, competition, and human activity, among other causes). Thus, there is variation in numbers using any given beach throughout the stopover. With limited personnel and resources it is not feasible to survey every beach used by shorebirds every hour of every day. Thus sampling is essential. Although most shorebird surveys show a lot of zeros, shorebirds were present on over $85 \%$ of the censuses, and knots were present on over $48 \%$ of them. This allowed more conventional statistical approaches.

Finally, we standardized our longitudinal sample area (along the beach) to $300 \mathrm{~m}$, yet many of the beaches were much longer. If a large flock extended beyond our survey boundaries, we simply counted those birds that were within our survey boundary (leaving others out of our census). Thus our numbers represent conservative estimates for these beaches, and represent only the shorebirds (and knots) in that section.

\subsection{Conclusions from Our Intertidal Studies}

Demonstrating that shorebirds (and red knots) consistently use the intertidal regions of these beaches (out to $300 \mathrm{~m}$ ) may be more important than the actual numbers of birds present. Conversely, examining 
maximum numbers foraging on intertidal mudflats may be one method of estimating potential use. Shorebirds move around, so high numbers can be on one beach, and none on another, while on another day the reverse may be true. Thus overall means for all beaches combined (presented in Figure 5) do not tell the whole story. The difficulties of obtaining reasonable estimates of the number of shorebirds within a system that is changing rapidly means, we believe, that a number of studies over a number of years are required to adequately characterize the use of intertidal habitats by shorebirds. These studies need to be coupled with ongoing weight gain studies, to determine the fitness consequences of losing feeding habitat or food resource to any increase in human disturbance (e.g. recreation and aquaculture).

\section{COMPETING CLAIMS TO RED KNOT HABITAT AND PREY RESOURCES}

Red Knots that arrive on Delaware Bay are resource-limited and time-limited. They require habitat for roosting, resting, and foraging, and this habitat must be sufficiently undisturbed by people (or predators) so that they can gain enough weight to make the journey to northern breeding grounds in a short period of days. The beaches of Delaware Bay are far less used by recreationists than are those along the Atlantic Coast [39], and recreational beach access is severely restricted during the migration period. It is

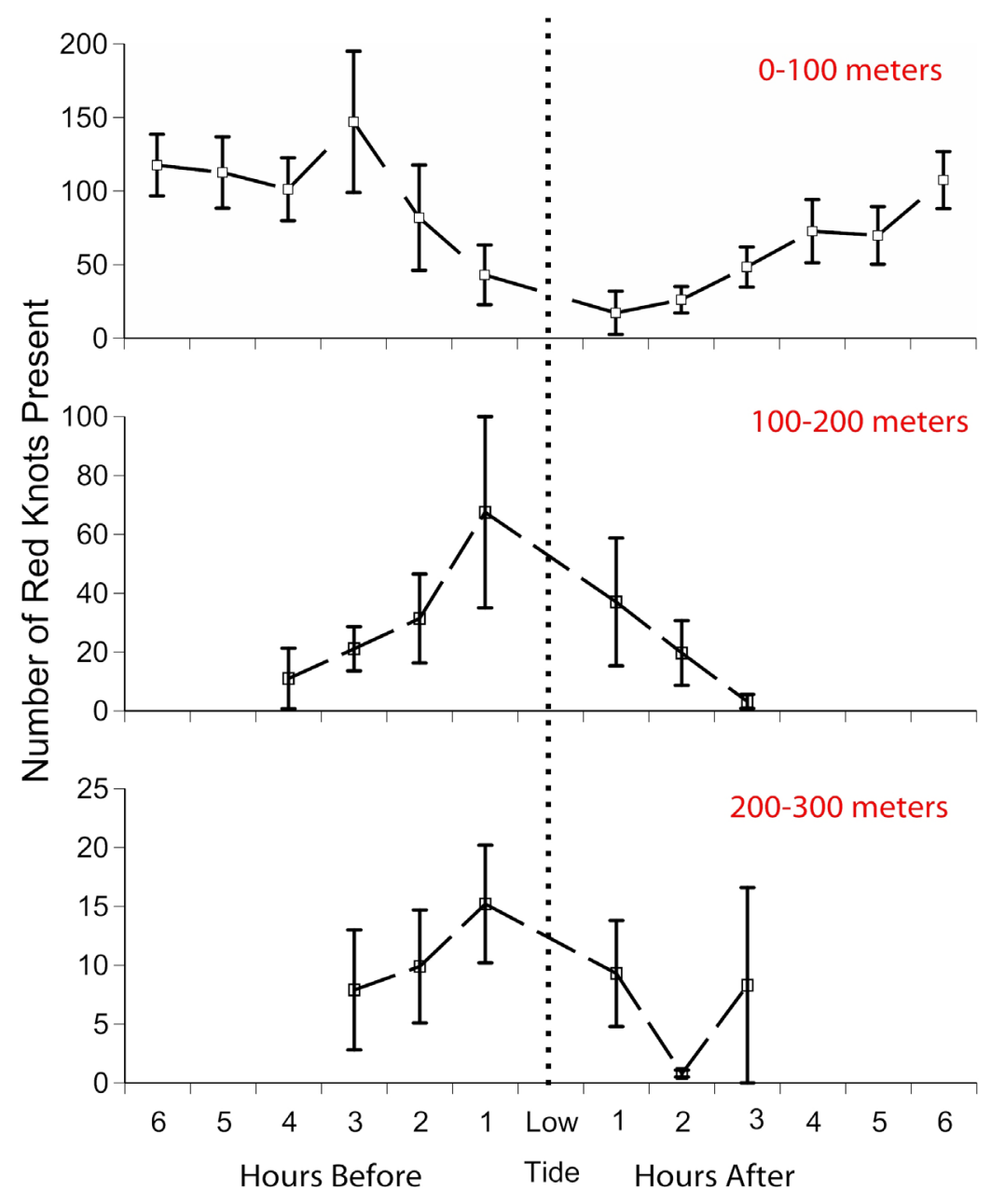

Figure 5. Mean number of Red Knots/census as a function of tide and location on the intertidal mudflat in 2016 (distances were $0-100 \mathrm{~m}, 101-200 \mathrm{~m}$, and $201-300 \mathrm{~m}$ from mean high tide). 
the "Jersey Shore" that is the destination for thousands of people each summer, and that hosts a continuous band of houses, rental properties, marines, boardwalks, bars, businesses, and other establishments from Sandy Hook to Cape May. However, people living in local towns and owning houses along the Delaware Bay beaches do use the beach for walking, jogging, walking dogs, sun-bathing, fishing, and off-road vehicles. Most of the key knot foraging beaches are off-limits to people during May when the red knots and other shorebirds are migrating through.

Red knots and other shorebirds are facing three main competing claims: 1) recreational uses of the beaches, 2) harvest of horseshoe crabs for bait and the medical lysate industry (removing blood from crabs), and 3) use of the intertidal by human activities. Since recreational access to the beaches is restricted during May, the activities associated with aquaculture (a recent use) become the dominant human activity impinging on shorebird feeding time and space. Each of these uses competes with the others: if there are too many people, shorebirds are disturbed and leave $[9,26,37,38]$. If there is not enough food, the shorebirds cannot gain enough weight to make it to the Arctic and breed [22]. And if there is no space to feed (due to presence or activity of human disturbance), then the shorebirds will not gain sufficient weight to make it to their breeding grounds $[8,19,22,34,38]$. Thus there are competing claims for the beach and intertidal habitat on Delaware Bay and elsewhere in the U.S. [35].

\section{ROLE OF STAKEHOLDERS}

Competing claims for habitat (beach, intertidal) and the resources (e.g. horseshoe crab eggs) requires a consensus process or structured-decision making process. Each of the three main competing claims (recreationists, fishermen, aquaculturalists) require different, but similar approaches, only the stakeholders change, and the activity being managed. Moreover, in all three cases, an adaptive management strategy whereby new data triggers new responses is required. The process for dealing with the use of horseshoe crabs for bait and lysate (fisherman stakeholders) has had more time to develop a management strategy than the others.

\subsection{Horseshoe Crab Harvest}

There are few ecological problems as contentious as the management and harvesting of horseshoe crabs, and the relationship between declining migrant shorebird numbers and the abundance of horseshoe crab eggs on Delaware Bay. The process of including stakeholders was initially very difficult, as was the concept of multi-species management (for values other than harvest quotas). Although authority for setting harvesting quotas resides with the Atlantic States Marine Fisheries Commission (ASMFC [32]), there is a complex series of committees and procedures to set these limits, often involving technical committees with representatives from the regulated states, as well as input from a range of stakeholders. There is a regulatory framework that includes interested and affected parties that have input to the harvest limits and quotas. The process used to resolve conflicts was a new paradigm that used structured decision making (SDM) within an adaptive resource management framework (ARM). While the new paradigm that included SDM and ARM resulted in inclusion of a wide range of stakeholders (state and federal agencies, conservation organizations, biomedical industries and fisheries, scientists and other publics, see Table 4), it was difficult to implement this paradigm within the time constraints of the ASMFC, particularly with pressure from both fisheries regulatory bodies and fisheries practitioners. Even so, the ASMFC's management plan for horseshoe crabs is a multispecies plan (including the needs of shorebirds), rather than just managing populations of horseshoe crabs. Although the ARM framework represents an advance within the existing fishery management system, it has not yet resulted in increases in the populations of horseshoe crabs, or in the number of spawning females [40]. There are on-going studies to identify why numbers have not increased, including the role of the Lysate industry. The various stakeholders involved in the process of developing the structured decision making process and the ARM framework need to have a greater role in the harvest decisions, rather than it being a decision taken entirely by the ASMFC Management Board, a group dominated by commercial fishing interests. 
Table 4. Stakeholders with an interest in the horseshoe crab-shorebird community interactions. The main categories of stakeholders (in order in the table) are 1) federal agencies and committees, 2) state agencies, councils and committees, 3) conservation organizations and river keepers, 4) biomedical, fisheries (individuals and companies) and other businesses, 5) scientists, and 6) the general public (see also Burger et al. [39] for stakeholder involvement from a different perspective). These are examples, and not meant to be exhaustive.

STAKEHOLDERS FUNDING/REPORTING
Atlantic States Marine
Fisheries Commission NOAA
(ASMFC)
Horseshoe crab
$\begin{aligned} & \text { Management } \\ & \text { Committee (HCMC) }\end{aligned}$

Horseshoe crab Technical Committee (HCTC) NOAA, reports to HCMC, interacts with STC.
Manage fisheries for sustainable harvest and populations

Manage horseshoe crab populations with mandate of protecting them and shorebirds

(multi-species approach). Mandate is protection and development of harvest quotas

Provide scientific, technical information and recommendations, (mainly on horseshoe crabs) to inform the horseshoe crab Management Committee. Direct and acquire data and construct models as needed

Provide scientific data on shorebirds aimed at restoring and protecting shorebirds, particularly the red knot (A US candidate species)

Protect all fish and wildlife, including endangered, threatened, and species of special concern.

US Fish \& Wildlife Service

Department of the Interior Interested in sufficient stakeholder participation. Responsible for protecting red knots (a threatened species), as well as other shorebirds Main interests in Biology, geography, geology, geospatial, and water. Protection of all fish and U.S. Geological Survey

Department of Interior wildlife, and in providing sufficient data and expertise to manage populations. Provide expertise on horseshoe crab populations and dynamics

Protect all wildlife in New Jersey, including endangered, threatened and species of special concern. Manages declining populations, and

Endangered and Nongame Program

New Jersey Department of Environmental Protection (Division of Fish and Wildlife) provides data to aid in management decisions. Interested in the horseshoe crab-shorebird interactions from an ecological perspective

Endangered and NJ Endangered and Nongame Advisory to the Program, interested in protecting Nongame Advisory Program of the NJ Department all wildlife within New Jersey, and in maintenance Committee of Environmental Protection of healthy ecosystems, including Delaware Bay 


\section{Continued}

\begin{tabular}{|c|c|c|}
\hline $\begin{array}{l}\text { Bureau of Marine } \\
\text { Fisheries }\end{array}$ & $\begin{array}{l}\text { New Jersey Department of } \\
\text { Environmental Protection } \\
\text { (Division of Fish and Wildlife) }\end{array}$ & $\begin{array}{l}\text { Responsible for managing sustainable } \\
\text { populations of harvested fish and shellfish } \\
\text { (for both commercial and recreational uses) }\end{array}$ \\
\hline $\begin{array}{l}\text { Marine Fisheries } \\
\text { Council }\end{array}$ & $\begin{array}{l}\text { New Jersey Department of } \\
\text { Environmental Protection } \\
\text { (Division of Fish and Wildlife) }\end{array}$ & $\begin{array}{l}\text { Interested in maintaining healthy, viable, and } \\
\text { where possible, harvestable populations of fish } \\
\text { in marine and coastal waters. Interested in } \\
\text { maintaining the bait industry (horseshoe crabs) } \\
\text { as well as healthy fish stocks, and a healthy } \\
\text { Delaware Bay ecosystem }\end{array}$ \\
\hline $\begin{array}{l}\text { Bureau of Marine } \\
\text { Fisheries }\end{array}$ & $\begin{array}{l}\text { Delaware Department of } \\
\text { Natural Resources and } \\
\text { Environmental Control } \\
\text { (Division of Fish and Wildlife) }\end{array}$ & $\begin{array}{l}\text { Protect and manage populations of fish and } \\
\text { shellfish. Interested in horseshoe crabs as } \\
\text { bait for fisheries }\end{array}$ \\
\hline $\begin{array}{l}\text { Marine Fisheries } \\
\text { Council }\end{array}$ & $\begin{array}{l}\text { Delaware Department of } \\
\text { Natural Resources and } \\
\text { Environmental Control } \\
\text { (Division of Fish and Wildlife) }\end{array}$ & $\begin{array}{l}\text { Advise the Bureau of Marine Fisheries, } \\
\text { interested in protect, enhancing and managing } \\
\text { harvestable fish and shellfish. Interested in } \\
\text { horseshoe crabs as bait for fisheries }\end{array}$ \\
\hline $\begin{array}{l}\text { Natural Heritage and } \\
\text { Endangered Species } \\
\text { Program }\end{array}$ & $\begin{array}{l}\text { Delaware Department of } \\
\text { Natural Resources and } \\
\text { Environmental Control } \\
\text { (Division of Fish and Wildlife) }\end{array}$ & $\begin{array}{l}\text { Mandated to protect fish and wildlife in the } \\
\text { state, especially endangered and threatened } \\
\text { species, and species of special concern }\end{array}$ \\
\hline New Jersey Audubon & New Jersey Audubon & $\begin{array}{l}\text { Initially protection of shorebirds } \\
\text { (including the red knot), the provision of } \\
\text { sufficient horseshoe crab eggs for the } \\
\text { shorebirds, and more recently the crabs } \\
\text { themselves in a Delaware Bay context }\end{array}$ \\
\hline
\end{tabular}

Other Independent

Conservation Groups:

New Jersey Conservation

Main interest is in preserving and protecting

Foundation, Littoral populations of shorebirds

Society, Defenders of Independently funded (focused on red knot as a keystone species), Wildlife, Conserve horseshoe crabs, and the keystone role of

Wildlife Foundation of NJ, horseshoe crabs in the ecosystem

Citizens United to Protect

the Maurice River

\begin{tabular}{lll}
\hline Delaware River Keeper $\quad \begin{array}{l}\text { Private contributions and } \\
\text { foundations }\end{array}$ & $\begin{array}{l}\text { Mainterest is in preserving, protecting, and } \\
\text { promoting the Delaware River and associated } \\
\text { resources. Also has an education } \\
\text { focus about the Bay }\end{array}$
\end{tabular}




\section{Continued}

\begin{tabular}{|c|c|c|}
\hline $\begin{array}{l}\text { Biomedical } \\
\text { Industries }\end{array}$ & Private companies & $\begin{array}{l}\text { Bleeding horseshoe crabs to produce } \\
\text { Limulus lysate for testing the purity of any } \\
\text { injectable solutions (in humans). The industry is } \\
\text { interested in maintaining sufficient populations } \\
\text { to allow bleeding }\end{array}$ \\
\hline $\begin{array}{l}\text { Fisheries and } \\
\text { Aquaculture }\end{array}$ & Private Industry & $\begin{array}{l}\text { Interested in maintaining healthy fisheries for } \\
\text { harvesting, including the use of horseshoe crabs } \\
\text { for bait for conch and eel } \\
\text { (both commercial and recreational). Commercial } \\
\text { production of oysters }\end{array}$ \\
\hline Other local industries & $\begin{array}{l}\text { Private industries, including } \\
\text { hotels, motels, restaurants, } \\
\text { sfishing and bait stores, nature } \\
\text { and bird-watching stores and } \\
\text { others. }\end{array}$ & $\begin{array}{l}\text { Interested in maintaining their businesses, and in } \\
\text { heaving a healthy Delaware Bay ecosystem, } \\
\text { increasing shorebird populations, and sufficient } \\
\text { horseshoe crab populations to draw tourists }\end{array}$ \\
\hline $\begin{array}{l}\text { Horseshoe crab and } \\
\text { shorebird study }\end{array}$ & $\begin{array}{l}\text { Virginia Technical Institute } \\
\text { Funded by US } \\
\text { Congressional mandate }\end{array}$ & $\begin{array}{l}\text { Conduct research on horseshoe } \\
\text { crabs and shorebirds }\end{array}$ \\
\hline Scientists & $\begin{array}{l}\text { Several Universities, including } \\
\text { Rutgers University-the State } \\
\text { University of New Jersey, } \\
\text { Stockton State College, } \\
\text { Royal Ontario Museum } \\
\text { (Canada), }\end{array}$ & $\begin{array}{l}\text { Conduct research on horseshoe crabs, shorebirds, } \\
\text { fish and wildlife, and the ecosystem of Delaware } \\
\text { Bay }\end{array}$ \\
\hline The Public & Private interests & $\begin{array}{l}\text { Includes a number of conservationists, } \\
\text { bird-watchers, and others interested in the } \\
\text { Delaware Bay ecosystem, and in horseshoe crabs as } \\
\text { a keystone species }\end{array}$ \\
\hline
\end{tabular}

\subsection{Recreation}

Addressing recreationists has been somewhat easier, in that the State of New Jersey can (and does) close the key beaches where the federally-threatened red knot forages (the beaches included in our study). Beach monitors are at the points (usually the end of roads) where people can access beaches, and there are signs and ropes indicating that the beach is off limits. Since the time the shorebirds are migrating through is largely limited to May and the first week of June, this does not provide an undue hardship (the big influx of people occurs after school finishes at the end of June). Stakeholders involved in managing recreationists on beaches that are critical for birds are indicated in Table 5). The success of reducing human disturbances on beaches largely rests with local communities, and their ability to engage community members and others in their conservation efforts. Different methods need to be developed for seasonal visitors, many of whom stay for a week or less, and may be unaware of the needs of foraging shorebirds.

\subsection{Aquaculture}

The emerging key issue is the desire to increase aquaculture along the New Jersey side of Delaware 
Table 5. The key role of stakeholders in managing recreationists on Delaware Bay to protect foraging shorebirds (after Burger et al. [39] and unpub). These are examples, and not meant to be exhaustive.

\begin{tabular}{|c|c|c|}
\hline STAKEHOLDERS & FUNDING/REPORTING & PERSPECTIVE \\
\hline Sea Grant & $\begin{array}{c}\text { National Oceanic and } \\
\text { Atmospheric } \\
\text { Administration (NOAA) }\end{array}$ & $\begin{array}{l}\text { Supports education and research to improve } \\
\text { coastal human and ecological communities }\end{array}$ \\
\hline $\begin{array}{c}\text { US Fish \& } \\
\text { Wildlife Service }\end{array}$ & $\begin{array}{l}\text { Department of the } \\
\text { Interior }\end{array}$ & $\begin{array}{l}\text { Protect all fish and wildlife, including endangered, } \\
\text { threatened, and species of special concern. Interested } \\
\text { in sufficient stakeholder participation, and in } \\
\text { protecting red knots (US threatened species), as well } \\
\text { as other shorebirds. Currently developing } \\
\text { management plans and goals for knot protection. Also } \\
\text { interested in encouraging public use of } \\
\text { beaches and intertidal habitats }\end{array}$ \\
\hline $\begin{array}{l}\text { Endangered and } \\
\text { Nongame Program }\end{array}$ & $\begin{array}{c}\text { New Jersey Department } \\
\text { of Environmental } \\
\text { Protection } \\
\text { (Division of Fish and } \\
\text { Wildlife) }\end{array}$ & $\begin{array}{l}\text { Protect all wildlife in New Jersey, including } \\
\text { endangered, threatened and species of special concern. } \\
\text { Manages declining populations, and provides data to } \\
\text { aid in management decisions. Interested in the horse- } \\
\text { shoe crab-shorebird interactions from a community } \\
\text { perspective. Provides funds and personal for research } \\
\text { with interactions between shorebirds and people, and } \\
\text { different types of recreation. Oversees beach stewards, } \\
\text { and engages in public education for recreationists. } \\
\text { Monitors shorebird presence to } \\
\text { understand which areas need protection }\end{array}$ \\
\hline $\begin{array}{c}\text { Local } \\
\text { Municipalities }\end{array}$ & $\begin{array}{l}\text { Local towns along the } \\
\text { Delaware Bay } \\
\text { (mayors, and other } \\
\text { officials) }\end{array}$ & $\begin{array}{l}\text { Participate in the closing of beaches, education, and } \\
\text { aid with restoration and management, while } \\
\text { encouraging recreation both for their residents } \\
\text { and/or economic interests }\end{array}$ \\
\hline $\begin{array}{l}\text { New Jersey } \\
\text { Audubon }\end{array}$ & New Jersey Audubon & $\begin{array}{l}\text { Protection of shorebirds (including the red knot), the } \\
\text { health of the beaches and intertidal habitat. } \\
\text { Education of recreationists about for red knot habitat } \\
\text { needs. Conducts research on interactions of } \\
\text { recreationists and shorebirds }\end{array}$ \\
\hline
\end{tabular}

Other Independent

Conservation Groups:

New Jersey Conservation

Foundation, Littoral

Society, Defenders of

Wildlife, Conserve

Wildlife Foundation of

NJ, CU-Maurice River
Main interest is in preserving and protecting populations of shorebirds (focused on red knot as a

Independently funded keystone species), horseshoe crabs, and the keystone role of horseshoe crabs in the ecosystem. Conducts research, and aids in research efforts, both on the Bay and elsewhere in the U.S. and South America 


\section{Continued}

\begin{tabular}{|c|c|c|}
\hline $\begin{array}{c}\text { Delaware River } \\
\text { Keeper }\end{array}$ & $\begin{array}{l}\text { Private contributions and } \\
\text { foundations }\end{array}$ & $\begin{array}{l}\text { Main interest is in preserving, protecting, and } \\
\text { promoting the Delaware River and associated } \\
\text { resources. Also has an education focus about the Bay, } \\
\text { and the responsible behavior of recreationists }\end{array}$ \\
\hline Scientists & $\begin{array}{l}\text { Several Universities, including } \\
\text { Rutgers University-the State } \\
\text { University of New Jersey, } \\
\text { Virginia Tech, Stockton State } \\
\text { College, Royal Ontario } \\
\text { Museum (Canada), and others. } \\
\text { Many scientists from overseas } \\
\text { participate in the Delaware Bay } \\
\text { Shorebird Project }\end{array}$ & $\begin{array}{l}\text { Conduct research on the interactions of recreationists } \\
\text { and shorebirds. Interacts with the public and } \\
\text { government to encourage protection of threatened } \\
\text { and declining species of shorebirds }\end{array}$ \\
\hline The Public & Private interests & $\begin{array}{l}\text { Includes a number of conservationists, bird-watchers, } \\
\text { and others interested in the Delaware Bay ecosystem, } \\
\text { and in optimizing their own recreational uses with } \\
\text { nature and survival of healthy shorebird populations. } \\
\text { Volunteer as beach stewards and in research projects }\end{array}$ \\
\hline
\end{tabular}

Bay. Traditionally, oyster harvesting was from natural sub-tidal oyster reefs, and was an important part of Delaware Bay culture [35]. The rack and bag method of oyster culture, started in the 1990s, has the potential to aid restoration of Delaware Bay beaches and ecosystems [41, 42], but it also has the potential to increase erosion and decrease intertidal foraging space for shorebirds, as well as access to spawning beaches for horseshoe crabs [33]. Because the rack and bag method is relatively new, and the desire to expand further along the coast is new, all of the players and their relative roles are unclear. Many of the potential benefits and harms are not known.

Yet, some stakeholders can clearly be identified (Table 6), with their appropriate roles. Since the impact of increased aquaculture on intertidal lands is relatively recent, all of the key stakeholders are not yet identified. Because the issue is recent, it provides an opportunity to adopt a structured decision making (SDM) process, with frequent and diverse stakeholder involvement, and an adaptive management strategy that can be modified whenever new information is available (such as we provide above for shorebird and [red knot] use of the intertidal). Implementation of such a process is under consideration. For many years, there were few requests for new leases, but this issue has now emerged as an important management one.

However, the landfall of Superstorm Sandy (in 2012) affected many state and local procedures, including emergency regulations. The recent process used to lease the intertidal zone was closed to stakeholders except commercial growers, who at first had nearly unrestrained access to the intertidal area. This was a result of the state DEP expanding aquaculture through the adoption of emergency regulations developed after damage from Hurricane Sandy, despite the growers incurring little damage from the hurricane. The emergency regulations allowed expansion with minimal environmental review and little consideration for horseshoe crabs and shorebirds using the same intertidal areas. No stakeholders except growers were involved or even notified of the changes, which were included within an extensive list of other regulations that dealt with actual hurricane-related damage.

Just prior to the implementation of the expansion, the red knot was federally listed as threatened, 
Table 6. The key role of stakeholders in resolving issues between aquaculture and red knot and other shorebird habitat needs. These are examples, and not meant to be exhaustive.

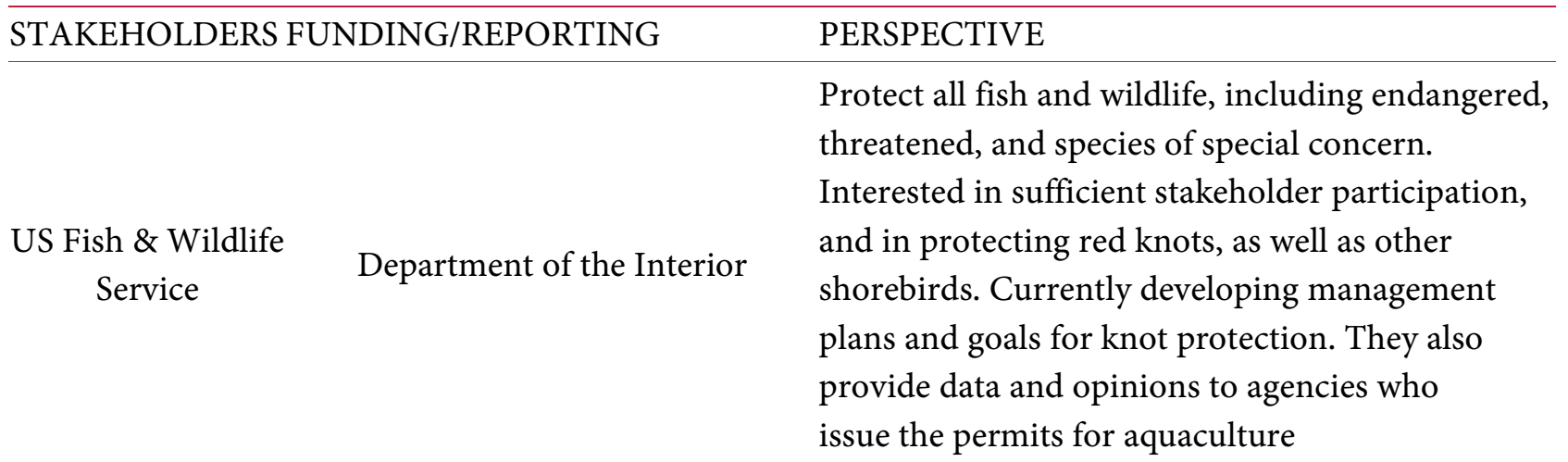

Sea Grant National Oceanic and Atmospheric Supports research on aquaculture and spe-

\begin{tabular}{|c|c|c|}
\hline Sea Grant & Administration (NOAA) & cies/ecosystem health \\
\hline $\begin{array}{l}\text { Endangered and } \\
\text { Nongame Pro- } \\
\text { gram }\end{array}$ & $\begin{array}{l}\text { New Jersey Department of } \\
\text { Environmental Protection } \\
\text { (Division of Fish and Wildlife) }\end{array}$ & $\begin{array}{l}\text { Protect all wildlife in New Jersey, including } \\
\text { endangered, threatened and species of special } \\
\text { concern. Manages declining populations, and } \\
\text { provides data to aid in management decisions. } \\
\text { Interested in the horseshoe crab-shorebird } \\
\text { interactions from a community perspective. } \\
\text { Provides information to the USFWS } \\
\text { about protection of knots relative to aquaculture }\end{array}$ \\
\hline $\begin{array}{l}\text { NJ DEP } \\
\text { U.S. Army Corp of } \\
\text { Engineers }\end{array}$ & $\begin{array}{l}\text { New Jersey Department of } \\
\text { Environmental Protection } \\
\text { (Division of Fish and Wildlife) }\end{array}$ & $\begin{array}{l}\text { Issues permits for building racks for rack and bag } \\
\text { aquaculture in the intertidal }\end{array}$ \\
\hline
\end{tabular}

Initially protection of shorebird habitat

New Jersey

Audubon

New Jersey Audubon (including for the red knot), Education efforts for red knots. Lobbying for appropriate laws and regulations of aquaculture, and protection of intertidal. Research on shorebirds in intertidal habitats

Other Independent Conservation

Groups: New

Jersey Conserva

tion Foundation,

Littoral Society,

Defenders of

Independently funded

Wildlife,

Main interest is in preserving and protecting populations of shorebirds

(focused on red knot as a keystone species), and in protection of shorebird

foraging habitat. Conducts research, and aids in research efforts, as well as lobbying for protective laws and regulations to protect the intertidal.

Conserve Wildlife

Foundation of NJ,

Provides volunteers for relevant research activities

CU-Maurice River 


\section{Continued}

\begin{tabular}{|c|c|c|}
\hline Scientists & $\begin{array}{l}\text { Several Universities, including } \\
\text { Rutgers University-the State } \\
\text { University of New Jersey, } \\
\text { Stockton State College, Royal } \\
\text { Ontario Museum (Canada), }\end{array}$ & $\begin{array}{l}\text { Conduct research on shorebird use of the intertidal } \\
\text { and behavioral responses of shorebirds to } \\
\text { aquaculture (structures, workers, schedules). Special } \\
\text { role for extension specialists to educate the public } \\
\text { about both aquaculture and needs of shorebirds and } \\
\text { other intertidal organisms }\end{array}$ \\
\hline The Public & Private interests & $\begin{array}{l}\text { Includes a number of conservationists, } \\
\text { bird-watchers, and others interested in the Delaware } \\
\text { Bay ecosystem, and intertidal ecosystem, and } \\
\text { foraging habitat for shorebirds (undisturbed) }\end{array}$ \\
\hline Aquaculture & Private Industry & $\begin{array}{l}\text { Interested in maintaining healthy oyster culture for } \\
\text { harvesting. Funds or conducts research on effects of } \\
\text { their activities on intertidal ecosystem. Interested in } \\
\text { health of shorebird populations }\end{array}$ \\
\hline
\end{tabular}

which forced industry advocates to compel the US Fish and Wildlife Service to allow expansion on the basis of economic hardship. The controversy over exploiting the inter tidal zone without any extensive understanding of the environmental impact ultimately forced growers to commit to a SDM process, the future of which is uncertain because of the lack of funding. Nonetheless, several opportunities for discussion of all viewpoints (aquaculture, horseshoe crab populations, red knot foraging needs and threatened status, and management/policy considerations) are being provided with the goal of an adaptive management strategy that involves best management practices for oyster culture.

\section{DISCUSSION}

\subsection{Use of the Intertidal}

The threats faced by red knots and other shorebirds on Delaware Bay and elsewhere are a matter of competing demands for habitat and other resources. The three main threats that shorebirds (and knots) face on Delaware Bay are human disturbance (beach), overharvesting of horseshoe crabs, and aquaculture's needs for intertidal space. One of the key issues is whether, and to what degree, shorebirds forage in the intertidal space desired for rack and bag aquaculture. The data presented indicate that shorebirds (and red knots) forage in the intertidal out to $300 \mathrm{~m}$, although the numbers decrease generally with distance from the shore. The shorebirds clearly move among the beaches, and this range of beaches may be required to provide adequate foraging space for red knots because of changing conditions, including where the horseshoe crabs spawned the previous night or two, wind conditions, tide conditions (e.g. intertidal space exposed), competitors (gulls), planes flying overhead, and other disturbances. These conditions may change daily, making it essential for shorebirds to have a wide range of beaches for foraging and roosting.

Further, one goal of placing a species on the threatened list is to recognize that the population needs to recover, and to do so means increasing the population to a reasonable size. Thus, the current low population of red knot (about 24,000 counted on Delaware Bay, with higher passage populations computed) should increase to two to four times that number. When this happens, the foraging birds will require even more crab eggs, more foraging space, and more beaches to provide the diversity needed so that there are always suitable places to forage regardless of weather, wind, water temperatures or crab spawning level. 


\subsection{Stakeholder Involvement}

On Delaware Bay, the red knots and other shorebirds are facing three major threats: recreation, fisheries, and aquaculture, and a wide range of stakeholders are essential to protect the shorebirds. Clearly, all three groups are interested in the health of the Delaware Bay ecosystem, and in preserving the shorebirds (and red knots). The issue is how to manage resource use (whether horseshoe crabs) or space. There are different regulatory structures involved in each. The take of horseshoe crabs is regulated by the ASMFC, in conjunction with states (e.g. NJ has a ban on taking horseshoe crabs in its waters. Delaware does not have a ban). The placement of aquaculture structures (racks) is dependent on leases provided by the NJ Department of Environmental Protection, and permits to build from the Army Corp of Engineers and the state. And recreationists are managed by both the state and local authorities.

Other stakeholders are important to all three threats. NGOs provide scientific data, volunteers for research and conservation efforts, lobbying for regulations to protect shorebirds and habitat, and information to the public. University scientists provide many of these same benefits (although not lobbying). Stakeholders and scientists can interact so that their individual efforts are greater together.

The industries also have a stake in the outcome, and they provide valuable services to their communities and states. They are interested in fostering and maintaining healthy ecosystems, which are essential to their resource use (horseshoe crabs), intertidal habitat use (building aquaculture racks), or recreation (beaches). They also provide scientific data, lobbying, and often volunteer for conservation or research projects.

All these stakeholder groups (regulatory and management agencies, NGOs, scientists, industry and recreationists) are essential to the wise management of the beaches and intertidal habitats. In our view, they all must work together to protect the health of the Delaware Bay ecosystem, including sufficient and necessary foraging habitat for shorebirds and horseshoe crabs, while maintaining healthy economicallyviable use of these resources.

\section{ACKNOWLEDGMENTS}

We thank the long-time researchers at Delaware Bay for monitoring shorebirds and providing data on shorebird use at low tide and for census data collection, Charlie Cummings, Stephanie Feigin, Mark Field, Steve Gates, Michael Gochfeld, Emily Hofmann; Joe Smith and for help during the study, and Taryn Pittfield and Christian Jeitner for technical and statistical analysis. This study was funded by the American Littoral Society, Rutgers University, Conserve Wildlife of New Jersey, and the Tiko Fund.

\section{REFERENCES}

1. Morrison, R.I.G. (1984) Migration Systems of Some New World Shorebirds. In: Burger, J. and Olla, B.L., Eds., Shorebirds. Migration and Foraging Behavior, Plenum Press, New York, 125-202.

2. Colwell, M.A. (2010) Shorebird Ecology, Conservation, and Management. University of California Press, Los Angeles.

3. Dey, A.D., Niles, L.J., DeRose-Wilson, A., Smith, J.A.M., Sitters, H.P., Morrison, R.I.G., Mizrahi, D. and Watts, B. (2016) Update to the Status of the Red Knot Calidris canutus in the Western Hemisphere, September 2016. Draft Update to Status of the Red Knot (Calidris canutus rufa) in the Western Hemisphere. New Jersey Environmental Department of Environmental Protection, Trenton.

4. National Research Council (NRC) (2008) Public Participation in Environmental Assessment and Decision Making. National Academy Press, Washington DC.

5. European Environment Agency (EEA) (2003) Environmental Indicators: Typology and Use in Reporting. EEA, Copenhagen. 
6. National Oceanic and Atmospheric Administration (NOAA) (2011) The Gulf of Mexico at a Glance. NOAA, Department of Commerce, Washington DC.

7. Baker, A.J., Gonzalez, P.M., Piersma, T., Niles, L.J., de Lima Serrano do Nascimento, I., Atkinson, P.W., Clark, N.A., Minton, C.D.T., Peck, M.K. and Aarts, G. (2004) Rapid Population Decline in Red Knots: Fitness Consequences of Decreased Refuelling Rates and Late Arrival in Delaware Bay. Proceedings of the Royal Society of London B, 271, 875-882. https://doi.org/10.1098/rspb.2003.2663

8. Niles, L.J., Bart, J., Sitters, H.P., Dey, A.D., Clark, K.E., Atkinson, P.W., Baker, A.J., Bennet, K.A., Kalasz, K.S., Clark, N.A., Clark, N.A., Clark, J., Gillings, S., Gates, A.S., Gonzalez, P.M., Hernandez, D.E., Minton, C.T., Morrison, R.I., Porter, R.R., Ross, R.K. and Veitch, C.R. (2009) Effects of Horseshoe Crab Harvest in Delaware Bay on Red Knots: Are Harvest Restrictions Working? Bioscience, 59, 153-164.

https://doi.org/10.1525/bio.2009.59.2.8

9. Goss-Custard, J.D., Triplet, P., Sueur, R. and West, A.D. (2006) Critical Thresholds of Disturbance by People and Raptors in Foraging Wading Birds. Biological Conservation, 127, 88-97.

10. Galbraith, H., Jones, R., Park, R., Clough, J., Herrod-Julius, S., Harrington, B. and Page, G. (2005) Global Climate Change and Sea Level Rise: Potential Losses of Intertidal Habitat for Shorebirds. USDA Forest Service Technical Report PSW-GTR-191.

11. Galbraith, H., Des Rochers, D.W., Brown, S. and Reed, J.M. (2014) Predicting Vulnerabilities of North American Shorebirds to Climate Change. PLoS ONE, 9, e108899. https://doi.org/10.1371/journal.pone.0108899

12. NOAA (National Oceanographic and Atmospheric Administration) (2012) Communities: The U.S. Population Living in Coastal Watershed Counties. http://stateofthecoast.noaa.gov/population/welcome.html

13. Intergovernmental Panel on Climate Change (IPCC) (2014) Climate Change 2014: Impacts, Adaptation and Vulnerability. Intergovernmental Panel on Climate Change. IPPC, Geneva. http://www.ipcc.ch/report/ar5/wg2

14. Statistical Analysis Systems (SAS) (2005) Statistical Analysis. SAS, Cary.

15. Burger, J., Hahn, D.C. and Chase (1979) Aggressive Interactions in Mixed-Species Flocks of Migrating Shorebirds. Animal Behavior, 27, 459-469.

16. Niles Niles, L., Burger, J., Porter, R.R., Dey, A.D., Minton, C.D.T., Gonzalez, P.M., Baker, A.J., Fox, J.W. and Gordon, C. (2010) First Results Using Light Level Geolocators to Track Red Knots in the Western Hemisphere Show Rapid and Long Intercontinental Flights and New Details of Migration Paths. Wader Study Group Bulletin, 117, 1-8.

17. Burger, J., Niles, L., Porter, R.R., Dey, A.H., Koch, S. and Gordon, C. (2012) Migrationg and Overwintering of Red Knots (Calidris canutus rufa) Nesting along the Atlantic Coast of the United States. Condor, 114, 302-313. https://doi.org/10.1525/cond.2012.110077

18. Baker, A., Gonzalez, P., Morrison, R.I.G. and Harrington, B.A. (2013) Red Knot (Calidris canutus). In: Poole, A., Ed., The Birds of North America Online Cornell Lab of Ornithology, America Online, Ithaca. http://bna.birds.cornell.edu.bnaproxy.birds.cornell.edu/bna/species/563

19. Niles, L.J., Sitters, H.P., Dey, A.D., Atkinson, P.W., Baker, A.J., Bennett, K.A., Carmona, R., Clark, K.E., Clark, N.A., Espoz, C., González, P.M., Harrington, B.A., Hernández, D.E., Kalasz, K.S., Lathrop, R.G., Matus, R.N., Minton, C.D.T., Morrison, R.I.G., Peck, M.K., Pitts, W., Robinson, R.A. and Serrano, I.L. (2008) Status of the Red Knot, Calidris canutus rufa, in the Western Hemisphere. Studies in Avian Biology, 36, 1-185.

20. Burger, J., Niles, L. and Clark, K.E. (1997) Importance of Beach, Mudflat, and Marsh Habitats to Migrant Shorebirds on Delaware Bay. Biological Conservation, 79, 283-292.

21. Burger, J. (2017) Birdlife of the Gulf of Mexico. Texas A \& M Press, Corpus Christi. 
22. Morrison, R.I.G., Davidson, N.C. and Wilson, J.R. (2007) Survival of the Fattest: Body Stores on Migration and Survival in Red Knots, Calidris canutus islandica. Journal of Avian Biology, 38, 479-487. https://doi.org/10.1111/j.0908-8857.2007.03934.x

23. Tsipoura, N. and Burger, J. (1999) Shorebird Diet during Spring Migration Stop-Over on Delaware Bay. Condor, 101, 635-644. https://doi.org/10.2307/1370193

24. Burger, J. and Niles, L.J. (2012) Shorebirds and Stakeholders: Effects of Beach Closure and Human Activities on Shorebirds at a New Jersey Coastal Beach. Urban Ecosystems, 16, 3.

25. Burger, J., Carlucci, S.A., Jeitner, C.W. and Niles, L. (2007) Habitat Choice, Disturbance, and Management of Foraging Shorebirds and Gulls at a Migratory Stopover. Journal of Coastal Research, 23, 1159-1166. https://doi.org/10.2112/04-0393.1

26. Schlacher, T.A., Nielsen, T. and Weston, M.A. (2013) Human Recreation Alters Behavior Profiles of NonBreeding Birds on Open-Coast Sandy Shores. Estuarine, Coastal, and Shelf Science, 118, 31-42.

27. Wilson, A. and Bonaparte, C.L. (1835) American Ornithology. Porter \& Coates, Philadelphia.

28. Chapman, F.M. (1923) Handbook of Birds of Eastern North America. Dover Publications (1966 Printing), New York.

29. Niles, L., Burger, J. and Dey, M. (2012) Life along the Delaware Bay: Cape May, Gateway to a Million Shorebirds. Rutgers University Press, New Brunswick.

30. Burger, J. and Niles, L. (2104) Effects of Closure and Human Activities on Shorebirds at Coastal Brigantine Beach. Urban Ecosystems, 16, 657-673. https://doi.org/10.1007/s11252-012-0269-9

31. Burger, J. and Niles, L. (2015) Closure versus Voluntary Avoidance as a Method of Protecting Migrating Shorebirds on Beaches in New Jersey. Wader Study Group Bulletin, 120, 20-25.

32. Atlantic States Marine Fisheries Commission (ASMFC) (1998) Interstate Fishery Management Plan for Horseshoe Crab. ASMFC, Washington DC.

33. Burger, J., Niles, L., Dey, A.D., Dillingham, T., Gates, A.S. and Smith, J. (2015) An Experiment to Examine How Red Knots Calidris canutus rufa and Other Shorebirds Respond to Oyster Culture at Reed's Beach, Delaware Bay, New Jersey. Wader Study Group Bulletin, 122, 89-98. https://doi.org/10.18194/ws.00011

34. Burger, J. and Niles, L. (2017) Habitat Use by Red Knots (Calidris canutus rufa): Experiments with Oyster Racks and Reefs on the Beach and Intertidal of Delaware Bay, New Jersey. Estuarine, Coastal, and Shelf Science, 194, 109-117.

35. Munroe, D. and Calvo, L. (2015) Shellfish Farmers and Restoration Scientists Finding Common Ground. Estuary News, 25, 8-9.

36. Siegel, S. (1956) Nonparametric Statistics for the Behavioral Sciences. McGraw-Hill, New York.

37. Burger, J. and Niles, L. (In Review) Importance of Intertidal Mudflats to Foraging Red Knots and Other Shorebirds during Low Tide at Delaware Bay, New Jersey. Wader Study Bulletin.

38. Burger, J. and Niles, L. (ms) Importance of Intertidal Mudflats to Four Species of Foraging Shorebirds.

39. Burger, J., Gochfeld, M., Niles, L., Tsipoura, N., Mizrahi, D., Dey, A., Jeitne, C. and Pittfield, T. (2017) Stakeholder Contributions to Assessment, Monitoring, and Conservation of Threatened Species: Black Skimmer and Red Knot as Case Studies. Environmental Monitoring and Assessment, 189, 60. https://doi.org/10.1007/s10661-016-5731-3

40. Niles, L.J., Smith, J.A., Daly, D.F., Dillingham, T., Shadel, W., Danihel, M.S., Hafner, S. and Wheeler, D. (2013) Restoration of Horseshoe Crab and Migratory Shorebird Habitat on Five Delaware Bay Beaches Damaged by 
Superstorm Sandy. L.J. Niles Associates, Bordentown.

41. Hata, D. and Hallerman, E. (2017) Results of the 2016 Horseshoe Crab Trawl Survey: Report to the Atlantic States Marine Fisheries Commission Horseshoe Crab and Delaware Bay Ecology Technical Committees. Virginia Polytechnic Institute and State University, Blacksburg.

42. Subasinghe, R. (2006) State of World Agriculture 2006. FAO Fisheries Technical Paper, Rome.

Submit or recommend next manuscript to SCIRP and we will provide best service for you:

Accepting pre-submission inquiries through Email, Facebook, LinkedIn, Twitter, etc.

A wide selection of journals (inclusive of 9 subjects, more than 200 journals)

Providing 24-hour high-quality service

User-friendly online submission system

Fair and swift peer-review system

Efficient typesetting and proofreading procedure

Display of the result of downloads and visits, as well as the number of cited articles

Maximum dissemination of your research work

Submit your manuscript at: http://papersubmission.scirp.org/

Or contact ns@scirp.org 